Florida International University FIU Digital Commons

\title{
A Cross-Generational Analysis of Spanish-to- English Lexico-Semantic Phenomena in Emerging Miami English
}

Kristen Mullen

Masters of Linguistics Student, kmull026@fiu.edu

DOI: $10.25148 /$ etd.FI15050206

Follow this and additional works at: https://digitalcommons.fiu.edu/etd

Part of the English Language and Literature Commons, Latin American Languages and Societies Commons, Modern Languages Commons, and the Spanish and Portuguese Language and Literature Commons

\section{Recommended Citation}

Mullen, Kristen, "A Cross-Generational Analysis of Spanish-to-English Lexico-Semantic Phenomena in Emerging Miami English" (2015). FIU Electronic Theses and Dissertations. 1801.

https://digitalcommons.fiu.edu/etd/1801 


\title{
FLORIDA INTERNATIONAL UNIVERSITY
}

\author{
Miami, Florida
}

\section{A CROSS-GENERATIONAL ANALYSIS OF SPANISH-TO-ENGLISH LEXICO- SEMANTIC PHENOMENA IN EMERGING MIAMI ENGLISH}

\author{
A thesis submitted in partial fulfillment of \\ the requirements for the degree of \\ MASTER OF ARTS \\ in \\ LINGUISTICS \\ by \\ Kristen Mullen
}


To: Dean Michael R. Heithaus College of Arts and Sciences

This thesis, written by Kristen Mullen, and entitled A Cross-Generational Analysis of Spanish-to-English Lexico-Semantic Phenomena in Emerging Miami English, having been approved in respect to style and intellectual content, is referred to you for judgment.

We have read this thesis and recommend that it be approved.

Ellen Thompson

Melissa Baralt

Phillip M. Carter, Major Professor

Date of Defense: March 20, 2015

The thesis of Kristen Mullen is approved.

Dean Michael R. Heithaus

College of Arts and Sciences

Dean Lakshmi N. Reddi

University Graduate School

Florida International University, 2015 
(C) Copyright 2015 by Kristen Mullen

All rights reserved. 


\title{
ABSTRACT OF THE THESIS
}

\section{A CROSS-GENERATIONAL ANALYSIS OF SPANISH-TO-ENGLISH LEXICO- SEMANTIC PHENOMENA IN EMERGING MIAMI ENGLISH}

\author{
by \\ Kristen Mullen \\ Florida International University, 2015 \\ Miami, Florida \\ Phillip M. Carter, Major Professor
}

Sociolinguists have documented the substrate influence of various languages on the formation of dialects in numerous ethnic-regional setting throughout the United States. This literature shows that while phonological and grammatical influences from other languages may be instantiated as durable dialect features, lexical phenomena often fade over time as ethnolinguistic communities assimilate with contiguous dialect groups. In preliminary investigations of emerging Miami Latino English, we have observed that lexical forms based on Spanish lexical forms are not only ubiquitous among the speech of the first generation Cuban Americans but also of the second. Examples, observed in field work, casual observation, and studied formally in an experimental context include the following: "get down from the car," which derives from the Spanish equivalent, bajar del carro instead of "get out of the car". The translation task administered to thirty-one participants showed a variety lexical phenomena are still maintained at equal or higher frequencies. 


\section{TABLE OF CONTENTS}

CHAPTER

PAGE

1.0 Theoretical Background: Socially Oriented Empirical Linguistics .................. 1

1.1 The Role of the Lexicon in Dialectology .................................................. 5

1.2 The Role of the Lexicon in Sociolinguistic Inquiry .................................... 9

2.0 Review of Literature on Spanish/English Language Contact in the U.S. and

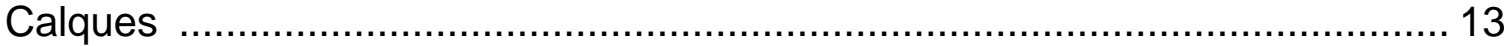

2.1 Language of Latinos in the U.S. Northeast ............................................ 13

2.2 Language of Latinos in the U.S. Southwest........................................... 20

2.3 Literature Review of Lexico-Semantic Phenomena and Calques..............26

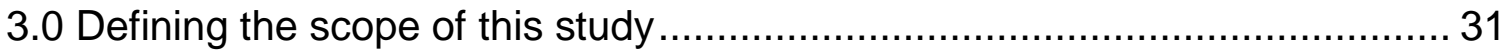

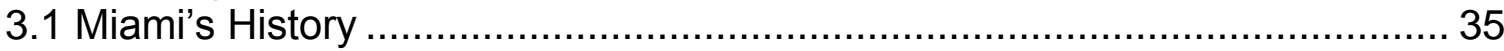

3.2 Other Research on Miami Latino English ................................................. 39

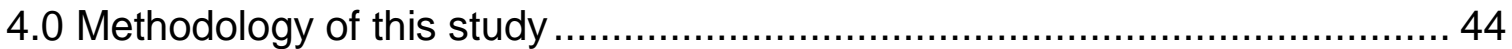

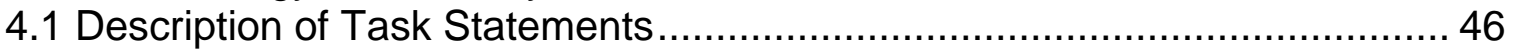

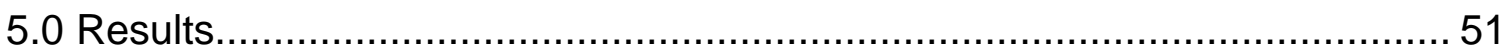

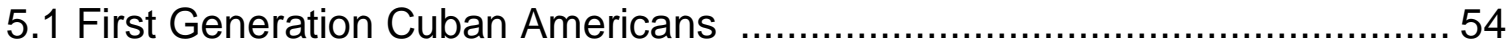

5.2 Second Generation Cuban Americans .............................................. 57

5.3 Comparison of Both Cuban American Generations ................................... 58

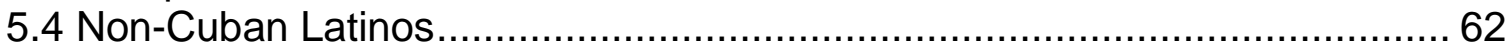

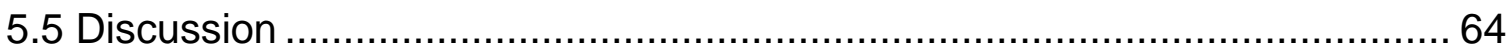

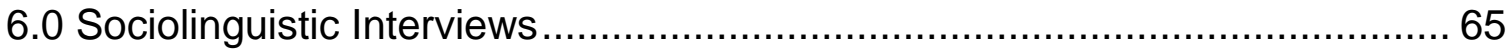

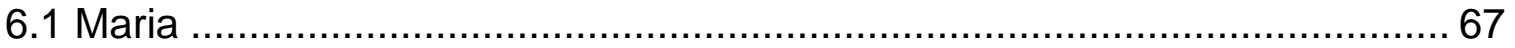

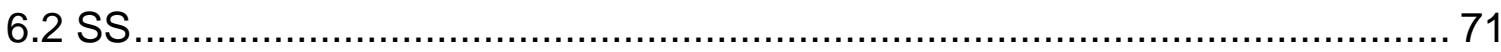

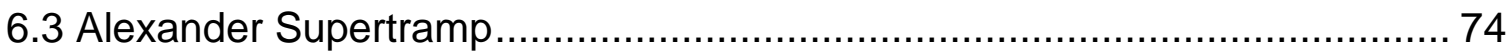

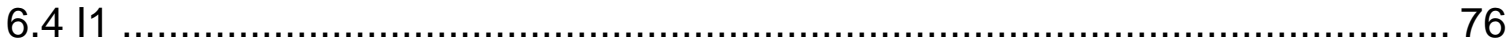

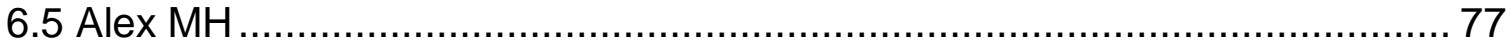

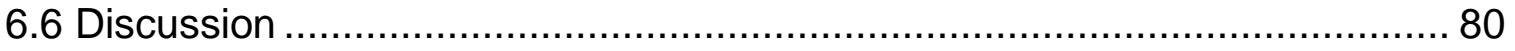

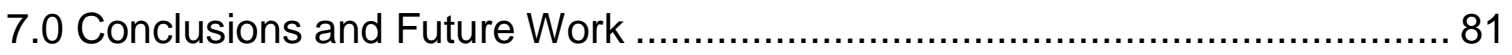

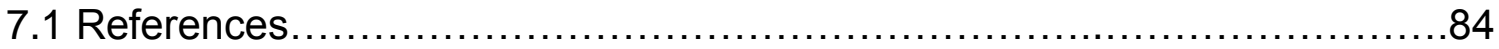


1.0 Theoretical Background: Socially Oriented Empirical Linguistics

The sociolinguistic research on varieties of languages is rich with studies on how differences in pronunciation, grammar and semantics correlate with the particular parameters of the social structure that determine its existence in a given speech community (Wolfram 1997). Some of the first groundwork for dialectal studies within society were carried out by William Labov (1963, 1966, 1972a, b), which challenged the established traditional assumptions of linguistics and dialectology. As most researchers furthered away from the traditional mapping and configuring of dialects to working in particular areas where variants and language shift occur. Labov was central to the idea that language must be studied in its social context in order to solve the problems in linguistic theory and description. In order to do this, Labov $(1962,1964,1972)$ collected data on language in its naturally occurring environment, through the use of conversational speech and what has now been termed, the sociolinguistic interview. The sociolinguistic interview was based on the assumption that naturally occurring speech reflects the most systematic data for the examination of language variation (Labov 1972) and on the assumption that the characterization of systematic variation should be integrated into the description of a language (Wolfram 1997). Therefore, when describing the mechanisms of language change and variation, the social context had to be included in the description and theoretical account. 
One of the most famous examples of a descriptive contextual study of language variation and social stratification was conducted by Labov in 1962 in New York City department stores. Labov's examination of the social stratification of $/ r /$ in NYC department stores in which he used a rapid and anonymous observation to study the sociolinguistic structure of a speech community led to the affirmation of his hypothesis: that groups of department store employees from Saks, Macy's and S. Klein are ranked by their differential use of $(r-1)$ (all the records that show $/ r /$ and no absence of $/ r /$; as defined by Labov) in such expressions as, fourth floor, in the same order as their stratification by non-linguistic factors. Thus, those employed by more prestigious department stores with better pay and working conditions, like Saks and Macy's, had higher tokens of ( $r-1)$ (more rhotic) than those who were employed by S. Klein. Labov's study is seen as the foundation for other studies on language variation and social stratification in the field of sociolinguistics, which have led to a proliferation of studies examining an arrange of linguistic and social variables. Additionally, Labov has a sufficient amount of related research apart from this study; (1962, 1963, 1972a, 1969, 1972, 1994, 1996). Among many others that concentrate on various ethnolinguistic communities in which phonological and syntactical variables occur, the basis and nature of language change as well the sociolinguistic considerations and additional applications for practical understanding of dialects and variants including applications for teachers in the education system and students. 
The field that cohered around the approach articulated by Labov and his contemporaries eventually became known as variationist sociolinguistics. The approach is exemplified in the work of scholars such as Wolfram (1970, 1977, 1981) and Trudgill (1974). Trudgill (1974) documented the co-variation of phonological and sociological of the variable (ng) in Norwich English to provide insight on the social class utilizing the (ng) variable and stylistic differentiation. The methods for this study were taken partly from Labov, as Trudgill incorporated casual speech as a variable into the calculations, but additionally he added in other variables such as a word list, reading passage and formal speech to portray individual and group phonological indices. Trudgill was able to investigate; (i) the nature of the correlation between realizations of phonological variables and social class, social context and sex, (ii) to discover which variables are subject to social class differentiation and which to stylistic variation and (iii) to find out which variables are most important in signaling the social context of some linguistic interaction or the social class of a speaker. He concludes that the proportion of the $/ \mathrm{n} /$ to $/ \mathrm{n} /$ endings deals with the social class of the speaker and the social context in which they are speaking (Trudgill 1974). This research set the foundation for his subsequent work on dialectal geography $(1980,1984,1990,2010)$, and further work with a sociolinguistic and dialect premise $(1992,2002,2003)$ among many others. As extensive as Trudgill's collection of work which incorporates a sociolinguistic standpoint towards dialectology research, it too, like Labov's work, provided an ample foundation for the successive work on phonological and syntactical research on 
various speech communities and those surfacing dialects. Subsequent research on the phonological and syntactical variations in various speech communities around the world and dialects has developed from the foundational work of both Labov, Trudgill and others.

The approach is also evidenced in the work of Walt Wolfram, as he is well known for his work on language variation $(1970,1987,1989,2013)$ and among many others. As well as his extensive work in dialectology (1970, 1981, 1982), among many others and with his comprehensive work on Appalachian Speech (1977, 1978,1979 1981 1984, 2013). Wolfram's research in a sense combines certain methodology from Labov and Trudgill, such as carrying out sociolinguistic interviews, especially in the state of North Carolina, but also in pioneering work on social and ethnic dialects that document mostly phonological and syntactical changes that in part have their hand in new dialects forming in the US.

I have reviewed the work of these sociolinguists in order to outline the major emphases of variationist sociolinguistics. I do not wish to imply that this work represents the whole of the field or its many modes of inquiry - it does not. This review provides a basis for this thesis, as it will work with the basic theoretical assumptions of variationist sociolinguistics work that have been illustrated by Labov, Trudgill and Wolfram, but not in the search for a clearer explanation of the phonology or syntactic structure of an emerging language variety in South Florida, but to intend on describing part of the emerging lexicon of this variety. As noted, pervasive work has been done on the phonology and 
syntactic structures of varieties not just by the previously mentioned scholars but by many in the sociolinguistics field; where little documentation exists is on how variants in the lexicon.

\subsection{The Role of Lexicon in Dialectology}

Traditionally, the core of the study of dialectology essentially focused on mapping the geographical location of a dialect on a linguistic atlas. The methods of categorization of a dialect in a given region mainly included collecting the lexical variations via questionnaires and then mapping them on a linguistic atlas. By the end of the $19^{\text {th }}$ century this work had already been well established in France (Gilliéron et al 1902, 1910) and Germany (Wenker 1926) and had transmitted to other parts of Europe and eventually to America. In the $20^{\text {th }}$ century established work in the field included research in Germany by Bach (1950), Dauzut (1944) and Pop (1950) on French and Kurath (1949), Kurath and McDavid (1961) in the United States which gave classical examples for successive work on the categorization of dialects in the United Kingdom (Brook, 1963) and other parts of Asia, including regional work on Japanese by Tokugawa and Kato (1966), Fujuwara (1967) and Kandori (1968) and Yiddish by Weinreich (1962, 1969) and further by Ramson (1970) on Australasian English, among others (Sankoff 1973) .

These traditional methods of dialectology of collecting unusual lexical items were utilized by Kurath in the 1930s when he constructed the Linguistic Atlas of the United States and what later became the Linguistic Atlas of New England (1939-1943). Kurath went further to include entries for individual sounds 
and grammatical constructions in his atlases as well. His methodology stemmed from the former classical examples mentioned in dialectal studies that had been carried out in Europe, such as identifying local born informants and giving them a list of prepared questions about names of common objects and activities of everyday life, household items, local flora and fauna, folk customs, etc. (Kim 2009). Using this data he categorized the US into three major dialect areas; North, Midland and South based on the phonological, morphosyntactic and of course the lexical variables. Further, Kurath published a lexical geography of the eastern U.S. in 1949 then later worked with McDavid in 1961 to create a phonological atlas of the Atlantic states. Other examples of lexicon-based dialectal geographies were carried out by Cassidy's in 1960 through 2009, as an extensive analysis of American English regional vocabulary called Dialect Atlas of Regional English (DARE) (Kim 2009).

By the 1960s predominately in the US but also in the UK, a new approach of studying variants and dialects began to shift from a regional account of differences in lexical, phonological and morphosyntactic forms to studying continuing variation and change in specific speech communities, such as urban areas, and also the inclusion of the linguistic variable to compare their quantitative relationship to social factors such as age, gender, socioeconomic status, ethnicity, style or internal linguistic factors (Labov 1963, 1966) (Trudgill 1974). As Kim (2009) states, 'Most of the research in the 1970s and 1980s was focused on social correlates of linguistic variation with less attention paid to the geographic dimension. During this period, pioneering scholars such as Labov, 
Trudgill, Wolfram and Eckert, succeeded in determining many of the fundamental principles of sociolinguistic variation.' (pg. 50) As Labov began his extensive work on the synchronic features and variation in African American Vernacular or AAVE, it had become more dominated by the historical debate regarding the origins of AAVE of the Creolist Hypothesis and the Anglicist hypothesis. This debate sparked a return to incorporate geographical variation in the 1980 s based on two substantial findings: 1) compiling evidence of fieldwork studies showed that several dialects of American English were not converging, but diverging from one another, contrary to what was assumed due to an increase of mass media and increased mobility and 2) AAVE and white vernaculars in places like the South and Northeast were not converging. These two findings along with the exslave narratives and the diaspora varieties of AAVE in the Dominican Republic and Nov Scotia were integral in disproving the origins of AAVE as a creole (Kim 2009). As successful as the findings were to the further understanding of the origins of $A A V E$ and the regression of a focus on geographical variation, one element, that was previously a key item in a further understanding of regional dialects seems to have gotten lost. The lexical element does not seem to reappear when geographical considerations in dialectology come forth again in the 1980 s in the U.S. As shown by work in the 1990s, most of the influential work done in this period was conducted by Labov, Ash and Boberg (2006) which has been famously titled the Telephone Survey of American English, recorded from 1992 to 1999 which produced the 2006, Atlas of North American English. This Atlas included telephone interviews of 762 English speakers across the US 
and Canada as a report on the regional phonology of English as dynamic rather than static (Labov, Ash, Boberg 2006).

Thus, as the lexicon proved to be one of the valuable elements in the description and mapping of regional dialects in rural dialectology, it appears that the importance of characterizing phonological variants overshadowed the importance of the lexicon somewhere along the transition to modern dialectology and language variation studies in variationist sociolinguistics. Therefore, current variationist sociolinguistics is rich with research in other subfields such as phonology and grammar but a clear void has been left in the study of lexicons. The examinations of lexicons provide integral information on the development of dialects, in this particular case, the Miami Latino English dialect. Studying the variant lexemes of this dialect shows how Spanish words and expressions influence the English dialect and how these variants are becoming central forms in the coming generations. This situation is particularly unique, as in most Spanish to English contact situations, English has remained the dominant driving force of influence over Spanish and other languages. This research will not only describe variants lexemes in an emerging dialect, but it also provide data on the influence of Spanish in the region measured over time. 


\subsection{The Role of Lexicon in Sociolinguistic Inquiry}

As the beginnings of the field of sociolinguistics would demonstrate, much attention was given to language change rather than the place of a dialect on a map. Modern sociolinguistic inquiry of distinct varieties of languages focuses on the differences in phonology, syntax and semantics among languages, with relatively little attention given to the study of distinct lexical choices a group of speakers make that is not quite considered the 'standard'. Integrated work on how alternative lexicons influence a variety is still not as abundant. Despite that fact, there still is current work being done on the lexicon. The following work describes the role the lexicon has taken in current sociolinguistic inquiry.

Such descriptions by Kiesling (2003) demonstrate consideration for lexical variants, as in this case the term Dude, as it is examined as a discourse marker, to not only address men but indeed women or a mixed gender group, and is more commonly used to encode the speaker's stance to his or her addressee. When used by the interlocutor, Dude encodes, a cool solidarity, as described by Kiesling that acts also to represent masculinity. Kiesling's methodology for capturing the term Dude, was in the form of an assignment given to undergraduate students in a sociolinguistic class at University of Pittsburgh in 2001 and 2002. Students were asked to record tokens of dude throughout a three-day period, while also noting the gender and ethnicity of the addresser and addressee. Kiesling found 519 tokens of Dude, used by mostly young men but also in female to female interaction (Kiesling 2003). This work outlines current 
trends in lexical variant studies and how this particular form has transformed semantically over a short period of time.

Elbe (1996) describes the lexical items that we call slang and how they are shaped and created in discourse. Elber states that slang words cannot be reliably distinguished from other vocabulary items by how they sound or how they are constructed, as they can be similar to other creations that stem from older words or part of words or have similar qualities to metaphors, irony and metonym. Thus, from the start of her work, Elber suggests that slang is just as creative and adds a unique element to our vocabulary such as these other literary items. But, it doesn't end there, Elber describes slang as having other significance as well; slang is used to describe people, relationships, social behavior, as well as it is deliberately chosen to send a social signal, to mark informality, irreverence, defiance, to add humor or to make one's inclusion in, admiration for, or identification with a social group. Basically, slang is the part of the lexicon with attitude. Additionally, as fashion, slang can become more and less popular with time and either become part of the permanent lexicon or fade away. Elber's work gives essentially a survey for what exactly slang is and what it's not. Additionally, she discusses how these terms positively add to the lexicon and are not deterrents of a variety.

Other research has encompassed lexical variation within diverse dialects with an established identity, such as in Scottish English (2014), where this research described the way in which native speakers of Scottish English diverged from traditional lexical usage based on historical events; changing their 
dialect, Scots, to the Standard English as the rewards for associating with the use of English were considerably greater than was the case for Scots. Further, as the professional educated class began using more and Standard English, the lexical 'improvers' of the Scottish language, were averted but as Millar, McColl, Bonnici (2014) point out, the middle class continued to use their vernacular well into the $19^{\text {th }}$ century as it was considered a staple of their identity even as those who wrote in Scots, may have been associated with a range of political beliefs which were definitely in opposition to the prevailing orthodoxies and be analyzed as radical. Part of this opposition could be seen as being oriented around linguistic expression of Scottish identity in the face of unionist hegemony. Thus, some Scot's lexis are used as an overt highly conscious of Scottish identity. However, it has been noted that Scots dialects, while retaining their many of their phonological and structural features, are gradually losing their specific lexis, known as lexical attrition (Millar, McColl, Barras, Bonnici 2014). Johnson (1996) describes where lexical variation and change are described to reveal synchronic patterns of variation by taking into account the social and regional variables of age, sex race, education, rurality, and region while documenting and analyzing how the lexicon has changed by comparing data that was collected in 1930 to 1990. This study incorporated 78 speakers across 62,500 square feet with birthdates that varied from 1847-1959. The goal of this paper was to document change in vocabulary across 55 years. 
Research by British sociolinguistic curator Robinson (2012) adds to the study of describing lexical variations within certain speech communities where he collected documented variations in British English by recording a set of group conversations about language, accent and dialect in locations across the UK by BBC local radio from 2004-2005. Recordings were taken from all types of people varying in socioeconomic class, age, gender, geographic location and ethnic background and etc, to see their responses to a set of prompt words. The results entailed a large, rich but targeted corpus of lexical variation (Robinson 2012). Investigations by Peirsman (2010) add to the diverse work done on lexical variation. Peirsman's work includes arguing that distributional semantics is the ideal framework for the investigation of such lexical variation. The study analyzed, two vernaculars, Belgian Dutch and Netherlandic Dutch, using a distributional model of the automatic retrieval of synonyms between dialects while addressing the problem of automatically identifying words that are typical of a given lect. The result of the research identifies ways in which distributional semantics can help research in variation linguistics with possible future applications for lexicography or terminology extraction (Peirsman 2010).

As this research works within the variationist tradition of studying new dialect formation in terms of substrate influence due to sustained language contact, but in doing so makes a commitment to the lexicon rather than to phonology and morphosyntax. The work relies on the bread and butter method of variationist sociolinguistics - the sociolinguistic interview (Labov 1963) - as well as an experimental elicitation task. Since this thesis is concerned not only 
with understanding the place of Spanish-influenced lexicon in Miami English, but also its durability over time, the elicitation task works with two generational groups - immigrants and children of immigrants. It is my hope to show how the study of the lexicon can be centralized in the sociolinguistic study of new dialect formation and language contact.

2.0 Review of Literature on Spanish/English Language Contact in the U.S. and Calques

As previously mentioned, the study on the prominence of lexico-semantic phenomena is quite limited, especially when concerned with the transcendence and adaptability of these lexico-semantic phenomena in emerging dialects. However, there have been some prominent studies dating back to the 1970 s that captured findings on other structural phenomena, lexico-semantic phenomena and calques. Calques can be defined as loan translations, in which the internal structure of a borrowed word or phrase is maintained but its morphemes are replaced by those of the native language. Like the phenomena being studied in this research, the studies that will be discussed in this chapter share a similar environment; where diverse ethnolinguistic communities interact. As most of the literature on these contact situations is focused more on the structural changes of Spanish rather than English, they will serve as a foundation on how the two languages interact in other contact communities and further attest to how unique the contact situation is in Miami. Further, these communities unlike Miami, do not hold Spanish to the same level of prestige as the communities in Miami do, thus it's understandable that the work described in this section pertain to how English influences structural changes in Spanish. 


\subsection{Language of Latinos in U.S. Northeast}

'Consisting of six New England states (Connecticut, Maine, Massachusetts, New Hampshire, Rhode Island, Vermont), plus New Jersey, New York and Pennsylvania, the Northeast was home to 5.2 million Hispanics or 15 percent, of the 35 million Hispanics in the USA in 2000.' (Zentella 2004) Zentella points out the most prominent group of Hispanics in NYC are Puerto Ricans at $36 \%$ and Dominicans at $18 \%$, of the 2 million Latinos living in on the region. As this data confirms, the vast majority of research done on Hispanic English in the Northeast is on Puerto Rican and Dominican Spanish in New York and as in contact with English on the island and its surrounding boroughs.

As various Caribbean Spanish dialects are in contact with one another and lexical leveling occurs between them, i.e. each ethnolinguistic community keeps their regional dialect but also acquires other words from other abutting dialects in contact. This inter-dialectal mix among the Spanish speaking communities also comes into contact with English and adds to the supply of available lexical items in each dialect. Such examples include the English loanword kite, and its adoption to many Spanish variants in contact because of the diverse forms of kite in each Spanish dialect (Zentella 2004). So to avoid confusion, most neighboring communities of different dialects, adopted kite in English rather than in Spanish, to make it less confusing when conversing with people who use another word for kite in their dialect. 
Additionally, as pointed out by Zentella (2004), Spanish-English bilingual speakers in the Northeast, utilize code-switching, to participate in two distinct communicative worlds; further Zentella attests to the bilingual complexity of speaking 'Spanglish' or code switching between Spanish and English. In addition to these morphosyntactic phenomena, Zentella points out further phenomena; English origin vocabulary in Spanish speaking, including monolingual speakers, lexicons' such as more direct examples as frizando or freezing. Other not as direct examples include, aplicación (application), papel (paper) and librería (library) (Zentella 2004).

Additional work by Zentella (1990) focuses solely on the lexical-leveling happening in New York City among diverse groups of Latinos, including, Dominicans, Cubans, Puerto Ricans and Columbians. Her work entailed investigating whether these diverse dialects of each group were sustaining their regional dialects, assimilated to the largest Spanish speaking group or created a different variety altogether, such as 'New York Spanish' lexicon. Zentella sought to find, 'How does extensive contact among such diverse groups affect each group's active knowledge of lexical variety in surrounding Spanish dialects and the ability of individual speakers to produce forms that are part of other groups' lexicons?'(pg. 1095) The experiment included 194 Hispanics identifying 25 objects as part of a 1-2 hour sociolinguistic experiment. The objects that Zentella used were common and also differed lexically for one or more of the nationalities studied. Participants were interviewed and asked them how they referred to each item in everyday conversation and if they knew another term for it. Zentella 
noted, the limitation of direct questions which elicit vocabulary items out of context in a formal situation, despite every attempt to overcome the 'observer's paradox'. (pg.1096) She submitted the responses to SPSSX and found that differences in age, gender, education, years in the US and Spanish or English proficient were insignificant as compared to national origin. Indeed, the national origin of the participants was the determiner of their choice of vocabulary with some revealing additions and exceptions. Although most utilized regional variants during in-group casual conversations, each group also accessed other lexical items for other conversations of out-group and more formal nature.

Zentella (1990) notes that it's difficult to determine the fate of words or expressions which are part of only one or two national lexicons. The lexical synonyms offered by her respondents revealed five different scenarios with implications for lexical loss, maintenance and leveling. An example of such scenarios includes, Scenario I called Majority Loss, her description notes common lexical items that are shared by the majority of the national origin groups that remain shared and unchanged, items such as, cadena for chain, collar for necklace and cartera for pocketbook. Scenario II describes Lone Exceptions, which described how three of the four national groups gave the same terms more often than any other but one group preferred another term. This scenario showed the convergence of some groups, like the Dominican, Puerto Ricans and Cubans for words like acerca, guagua and muebles but a divergence from the Colombian group's preference for anden, bus and sofa. However, other groups converged on other items, such as the convergence of Colombians, Puerto Ricans and 
Dominicans favoring carro for car. Among other convergences and divergences of the four national origin groups for the subsequent scenarios, it's clear that the nationally specific but minority lexical choices become inferior as far as usage, to the lexical item that is preferred by the majority of their co-nationals, according to Zentella, particularly if they are also endorsed by other groups, or they may be kept as markers of in-group styles. Zentella (1990) states, this amount of exposure approach to lexical leveling would lead us to predict that when common lexical items are in conflict, the one employed by the largest Spanish speaking group in they are i.e. Puerto Ricans in the Northeast, will be adopted (Zentella 1990).

In addition to this sample, she uncovered three linguistic factors and three social factors which establish barriers or incentives to co-existence, replacement, and/or specialization of meaning or style. She noted how certain words that become popular and then go out of style gives these items less semantic weight are subject to social and sometimes a gender variable. Further, some technologically advanced items that have no indigenous counterpart, gives stance to create new items for them as they do not exist in the homeland variant. Thus, these items are more subject to taking the English term for them, such example is blender in Spanish, from blender in English (Zentella, 1990).

Her study also found that linguistic structure does exert an influence, particularly in regard to homonyms. The tendency to avoid homonyms is in keeping with the fact that a linguistic system avoids the loss of contrasts, so as to minimize the possibility of mis-communication. Dialects in contact, such as the 
ones in this NYC study, show avoidance or translate taboo items in cross dialectal conversations. She also found that participants neutralized lexical conflict by using the English, the dominant language to better understand each other's Spanish. Additionally, as in most contact situations where borrowings from the dominant language were used more than the other way around, were also found in this sample. Thus, New York Spanish has often been termed 'Spanglish'. This is similar to the discourse around Miami Spanish, that most, more so the younger generations utilize Spanglish by incorporating Anglicisms and code-switching into their conversations. Anglicisms, as noted by Zentella can neutralize competing dialectal variants because the prestigious outside language acts as the lingua franca that resolves the conflict without favoring one group at the expense of another (Zentella 1990).

Zentella provides other social factors that also override linguistic similarities among the dialects in New York, such as the preference for dialects other than Dominican Spanish, even though Cuban, Puerto Rican and Colombian Spanish exhibit some of the same Caribbean Spanish features, the Dominicans are among the poorest, less educated and darkest in skin color when compared to their fellow Caribbean Spanish-speaking cohorts (Zentella 1990).

This study demonstrates how speakers of different dialects living in the same region utilize different lexical items depending on a variety of factors. These factors all lead to a situation where choices of words mark a variety of meanings. The knowledge and creatively of the national origin groups living in 
New York demonstrates the power that the lexicon has, in particular, the lexical choice has on each and every conversation not only among out-group interactions but also in-groups ones as well. This work by Zentella demonstrates the type of lexical studies in diverse dialects being done the US Northeast.

In addition to Zentella's work in the Northeast, one of the most well-known studies of code-switching was performed by Poplack (1982) in which the equivalence constraints, or the adherence of elements to both the surface syntactical rules of the L1 and L2 of balanced bilinguals during bilingual discourse, were studied to measure the degree of bilingual availability of the balanced and also non-fluent bilingual. Using recorded speech data in interviews and in natural settings of twenty-one Puerto Ricans residents in the famous Puerto Rican neighborhood of El Barrio in New York City, Poplack resulted that the balanced and non-fluent bilinguals were able to code-switch in sentences such as, 'But I wanted to fight her CON LOS PUÑOS, you know' (Poplack 1982) repeatedly without violating any syntactic rules in their L1 nor L2. Further, this study established the groundwork that code-switching, instead of being known as a clutch of the non-fluent bilingual in discourse, according to Pedraza (1978), it is actually an indicator of sophisticated bilingual dexterity.

Poplack's study also identified loanwords in the Spanish of the residents of El Barrio, which were adapted to Puerto Rican speech patterns and later categorized as monolingual Spanish discourse by Poplack. For instance, if the utterance demonstrated English phonological patterns by the balanced bilingual, it was considered an example of code-switching, as in number (1). However, if 
the interlocutor applied Puerto Rican speech patterns to the utterance, it was considered monolingual Spanish discourse, as in number (2): (Poplack, 1982)

(1) Leo un MAGAZINE [mægə'ziyn]

'I read a magazine'

(2) Leo un Magazine [maya'sin]

'I read a magazine'

Poplack also described other forms of loanwords such as constructions created by a loan English verbs such as 'to mug' to mogueen (they mug) as also considered a monolingual Spanish construction as it too, reflects a Spanish morphology, phonology and syntax (Poplack 1982).

Additional research by Newman (2010), presents New York Latino English or NYLE, in an ethnolinguistic repertoire, meaning it is a focused systematic dialect versus an unsystematic menu of features. As I believe Miami English is highly identified among other Floridians in phonological and lexical distinctions, Newman described NYLE as highly recognizable to New Yorkers, as NYLE speakers use a series of characteristic variants. His study assessed how systematic a sample of young-NYLE speakers are in their use of features indexing Latino identity. After recording and surveying twenty NYLE-youths, Newman analyzed the various variables by spectrogram and waveform such as the $/ \mathrm{b} /, / \mathrm{d} /$ and $/ \mathrm{d}, \mathrm{t} /$ in vocalic environments, $/ / /$ as the onset and using the $\mathrm{nPVI}$ scale ( ${ }^{*} \mathrm{nPVI}$ - normalized pairwise variability index) to measure stressed or syllable prosodic timing to further examine if a Spanish substrate variant could be found versus encountering an endogenous variable. 
The study in some respects, supported the view of New York Latino English as still not quite focused however, the results do suggest that there does seem to be a NYLE system, but the system is adopted to different degrees by different speakers (Newman 2010). Newman's study as many other investigations carried out on variants, dialects and ethnolects, focuses on the phonological variables that occurred while intending to identify the variant.

\subsection{Language of Latinos in U.S. Southwest}

Other studies such as work done by Silva-Corvalán (2004) documents the Spanish verb estar (to be) becoming more innovative syntactically and semantically than its counterpart the verb ser (to be). Silva-Corvalán documents how estar, is showing similarities to the verb "to be" in English especially when used in the progressive tenses. This research demonstrates how the extensions of innovative estar have already been progressing naturally in the Spanish in this region but that English has hastened this change.

Similarly, work conducted by Jenkins, (2003), shows how English may linguistically influence Spanish. Jenkins's work involved the Spanish verb, hacer in constructions where hacer preceded the infinitive in such examples as: hizo RETIRE (he/she did retire). These examples are part of Jenkins's research that was conducted in the US southwest. He discusses how English's influence on Spanish makes this innovative verbal paradigm possible.

Other work by Silva-Corlaván (2001) discuss lexical collaborations in the various parts of the US where she identifies the causes of such borrowings of words, particularly from English to Spanish, such as calques, and other lexemes 
like papel (paper) and registrarse (register). She further describes more unique creations where borrowed words from English adapt Spanish morphology like the additions of the verbal endings of -ar in Spanish with the word 'teach' in English to form, tichar for 'to teach' in Spanish. Other examples include, dostear, for 'to dust'. Further investigation reveals a question for how gender in Spanish gets assigned to borrowed words from English. Silva-Corlaván states that there are a variety a factors; 1) the physical gender of the referent, 2) The semantic association with the equivalent lexeme in the language that introduces the borrowed word (el lonche (lunch) for el almuerzo). 3) The identification with the phonologic form of the borrowed word with the form that requires feminine, masculine or neuter according to the rules of the receiving language (la hamburguesa to el hamburger as most words ending in $-r$ in Spanish receive masculine gender). Silva-Corlaván (2001) notes that Poplack and Pousada (1982) outlined the physiological factor that determines the category of grammatical gender for borrowed words, without exceptions. The phonological form of the word is also an important factor but is not as important as in Spanish and it was in French. Further, the semantic association with an equivalent lexeme in the receiving language is also a significant factor. All these factors contribute to the assignment of gender from Spanish to English in language contact situations and the result is a fascinating mixture of English borrowed words with often times mirroring Spanish phonology, semantics, syntax and gender assignments while maintaining, for the most part, the English lexemes. 
In describing language and the construction of ethnic identity, Fought (2003) discusses some features of Chicano English or Mexican English in which, code-switching, and it indexes multiple identities for Mexican Americans in Los Angeles. "Code-switching allows speakers to index these two types of memberships simultaneously." (pg. 25) Code-switching for Chicanos is just another way to identify being Mexican American rather than with an immigrant Mexican ethnicity (Fought 2008). Other works on code-switching and language as being indexical to identity were conducted by Mendoza-Denton (2008) of her ethnography on young Mexican Americans.

There are many analyses done about Chican@ English in the US, most of this work describes it as a distinct variety of American English in terms of morphology, syntax and grammar (Fuller 2013; Bayley \& Santa Ana 1985). Penfield, Ornstein-Galicia (1985) describe Chican@ English code-switching as a communicative style, that is social in nature and typical of a certain group of bilinguals who have acquired both languages in complex bilingual context. Similarly to Fought (2003) and Mendoza-Denton (2008), Penfield, OrnsteinGalicia (1985) make the same claim that it appears to be the choice of Chican@s when identifying with in-groups and Chican@ identity. Code-switching in the US Southwest among Chican@s shows the interaction of the two languages in the region:

A: Fuí ayer al doctor. Boy, they certainly make money. Me cobró twenty dollars. Fíjese a two minute visit y con trece pacientes en el 
office. Thirteen times twenty - son $\$ 260$. Además de lo que le pagan en los hospitals. Híjole! Por qué no me hice doctor instead of accountant. Además del puro mirar las cifras I'm getting blind. Qué barbaridad!

(Penfield, Ornstein,-Galicia, pg. 15)

Examples like these provide insight to the bilingual contexts where Spanish and English conjoin to form new forms of lexico-syntactic phenomena that adds to the varieties unique structure and vocabulary.

Not limiting Chican@ English to varying components, Silva-Corvalán's work on Chican@ Spanish describes the intensive vocabulary borrowings that mark Chican@ Spanish singular among other varieties of Latino Spanish in the US. Silva-Corlaván details the some, among many, manifestations of English influenced lexemes and verbs in Southwest Spanish (Silva-Corlaván 2004):

\begin{tabular}{|c|c|c|}
\hline Southwest Spanish & Standard Spanish & English \\
\hline Cama king & cama muy ancha & Very wide bed \\
\hline Lonche & almuerzo & lunch \\
\hline Esnak & refrigerio & snack \\
\hline Dompe & $\begin{array}{l}\text { (no word for yard } \\
\text { refuse that is dumped) }\end{array}$ & dump \\
\hline biles & cuentas & bills \\
\hline Puchar & empujar & to push \\
\hline
\end{tabular}


Mapear

Liquear

Grados pasar la fregona

gotear

notas to mop

to leak

grades

It's important to note the degree of lexical variations English origin words have influenced the Spanish in this region, just as Chican@ English, has received influence from Mexican Spanish in the region.

Analyses in this section have provided some examples of many of the work being done regarding Latino Englishes and Spanishes around the U.S. As demonstrated, code-switching, borrowing lexemes and structures between languages, in these cases Spanish and English, provides some overview on what takes place in two of the largest regions inhabited by Latinos in the U.S. Other literature will also indicate phonological and additional morphological forms included in surveys of Latino Englishes. The literature surveyed here provides insights on the lexico-phenomena and morphosyntactic structures that appear between Spanish and English that may very well appear in Miami English as well. Although these studies define the linguistic landscape of the contact situations, they do not show if these lexical phenomena are stable within the lexicons and structures. It is probably fair to say that code-switching is quite a durable feature of many of the Latino Englishes found across the U.S, however, what about the other lexical phenomena, like the borrowings or loan words like kite in Spanish? Studies on durability of lexical phenomena is quite limited in the linguistic literature in general and now, as one can see in the study of U.S. Latino 
Englishes as well. This research will provide pioneering analyses on lexicosemantic phenomena through generational analyses of the English lexicon by way of lexico-semantic phenomena as many of the previously studied Latino Englishes exhibit the many ways that English adds to the Spanish structure and lexicon.

This research attests to the unique view of Spanish in Miami, as how Spanish is influencing English. As previously mentioned, much of literature on these high contact situations between English and Spanish shows at times a dominating influence of English to Spanish. In Miami, we see both happening, but in particular to this research, we see a heavy influence from Spanish on the English of bilinguals here.

2.3 Literature Review of Lexico-Semantic Phenomena and Calques

Although this thesis focuses on a variety of lexical-semantic constructions, the bulk of the expressions studied can be understood to be calques. As such, I spend some time in this section reviewing the literature in linguistics on calque phenomena. Calque, a loan word used in English from French, means literally, 'copying or tracing'. That meaning stems from the Italian word calquer, 'trace' and from Latin calcare, 'to tread' (Oxford University Press 2015). Therefore, a calque is a loan word literally translated from one language to the next. The term calque itself is essentially a calque from French from English. Before the analyses of Spanish to English calques in the Miami lexicon and their durability among the first and second generation of Cuban Americans, literature on other calque situations will be provided to get a better 
sense of exactly how calques function in other ethnolinguistic contexts. I should also note here that the term calque although may be properly assigned to the first generations use of certain expressions from Spanish to English may not be appropriate for the English speaking second generation Miami born Cuban group, as this group was born in the US and are L1 speakers of English and also Spanish. Thus, calque may be used in addition to lexico-semantic phenomena in describing the second generation's lexicon because of a lack of better description of this phenomena. But it's important to note that this phenomena is happening with L1 English speakers in the second generation, not those who have unsuccessfully acquired an L2 language.

In English, we have a variety of words that have remained in our lexicon for centuries from a variety of loan translations or calques, from other languages. One can find many examples of calques from French and German in English lexicons, for example, the term, Adam's apple, originates from pomme d'Adam, in French as well as, free verse from vers libre, and point of view from point de vue. Examples from German include antibody from antikörper, homesickness from heimweh and loanword from lehnwort. These are few among many others from languages such as Arabic, Spanish, Chinese, Dutch, Latin and Hebrew. Thus, it appears that calquing is a very common feature among language contact situations and should be investigated further for emerging dialects, like this research in investigating Miami Latino English a possibly a new dialect in the region. 
The calques mentioned above have remained in our vocabulary for centuries and have become a stable part of our lexicon. Thus, it is not illogical to state that the calques in this study will not become stable features in the lexicon of Miami English. Although English plays a dominant role not only in the U.S. and outside of it, Miami, as previously mentioned, presents a unique situation in which Spanish is spoken across a variety of socioeconomic backgrounds and is associated positively; this is contrary, on some degrees, to the other English-Spanish contact situations that have been mentioned.

To provide a more comprehensive understanding of calques, in the sections that follow I review a variety of work that describes certain instances of calques but that also define certain types of calques. Defining certain calques will be important for this research as a variety of different types of calques or lexico-semantic phenomena appear in the speech of the first and second generation in Miami help in defining the lexico-semantic phenomena in this study.

Work by Alberdi Larizgoitia (2010) identifies Basque calques of French and Castilian origin and stresses the importance of calques based on their potential for enriching the Basque language by creating new words in general and in specialized vocabulary. 'Indeed, the word calque has become so contaminated with this pejorative idea that it is rarely counted as a valid resource for lexical creation...'(pg.16) The stance of this research on Spanish to English lexico-semantic phenomena or calques infers a similar view in that calques are part of a natural process of translating words and expressions in 
contact situations, and aide to enriching, not contaminating, the lexicon of languages. Alberdi Larizgiotia examines a variety of distinctly classified calques in Basque (from Spanish and French), such as semantic calques, which widened, or change/expand their significance when calqued from the source language to the targeted language and lexical calques, which are defined as translating the internal structure, pattern or internal form of a word of the source language into the target language. Such examples of semantic calques include indar in Basque which is a word for strength or force; it is used through a semantic calque in expressions like segurtasn-indarrak meaning 'security forces, forces of law and order'. Lexical calques into Basque include words such as prever (forsee) in Spanish to aurreikusi which literally means fore-see in Basque. Additionally, ferrocarril in Spanish and chemin de fer (railway) is calqued to burdinbide or irony-way in Basque. He further described different levels of lexical calques occurring in the Basque language, such as, literal lexical calques from English to Basque like, saskibaloi for basketball. Further, a near-calque or imperfect lexical calque, which are calques that are freer in the sense of the components of a compound word formation, meaning only one component is translated. Such examples include, año fiscal from Spanish to zergaurte in Basque, meaning fiscal year in English. And lastly, lexical calque induced by a foreign model, which is defined as a newly created word that is independently formed in the target language, yet has been influence by an external structure, for example, the French term automobile to kraftwagen in German (Alberdi Larizgoitia 2010). 
Further, Manea, Manea (2012) discuss the habitual use of English loan words and calques in modern Romanian. An example of a common calque from English to Romanian would be the use of the phrasal verb call back. Call back is directly translated from English to Romanian; Te sun ìnapoi. The text further suggests that since most Romanians have a good command of English, one can expect to see more English calques in the future.

Additionally, Harvey (1967) outlines the origin of the word mancebo positing that it is a calque from Arabic, meaning roughly a servant. The text suggests that calques have been utilized since 711 A.D.

Further, Orts LLopis, Sánchez-Lafuente (2009) site other findings of English to Spanish in peninsular Spanish. The text demonstrates that these loan words and calques aggregate in the economic lexicon of Spanish speakers in Spain today. Despite the Spanish equivalents for these words, most speakers prefer to utilize the English loan words and calques in everyday discourse for professions related around economics. Examples are given for the many loan words and calques that are now part of the Spanish lexicon. Such examples include, mercado de oso for bear market or bancarrota for bankruptcy and línea de crédito for line of credit.

Additionally, noted by Haugen (1950:214), the term rascacielos for skyscraper as a calque from English to Spanish. The English term skyscraper was literally translated into several languages to refer to tall buildings. Additionally, he mentions the ever-so-famous, te llamo para atrás, for 'call back' in Spanish. 
This thesis will look at lexico-semantic phenomena in subsets, as naturalist data sociolinguistics interviews and also as an experiment. As noted previously by Zentella (1990) 'the limitation of direct questions which elicit vocabulary items out of context in a formal situation, despite every attempt to overcome the 'observer's paradox'.' (pg.1096) Understanding this limitation of eliciting calques in direct questions in a formal situation, an experiment task was compiled to complement the findings in the corpus of sociolinguistic interviews currently being done at Florida International University. These experiments along with the interviews provide complementary insight on the lexico-semantic features, or calques of Miami Latino English.

3.0 Defining the scope of this study

Miami Latino English, as it has been termed (Carter, Callesano 2014) (Carter, Lopez, Sims 2014) (Mullen 2014) has emerged among the Miami born as presumably a new dialect of English. Research in this region provides data showing persistent substrate influence from Spanish on the English of second generation Miami Latinos, both in terms of vowel quality and prosodic rhythm (Carter, Lopez, Sims 2014) which will be mentioned in more detail. The claim being made is that Miami English bares the structural influence of Spanish in part because of population ecological factors in which a) an emerging, mostly bilingual Latino majority replaced a previously English monolingual Anglo White majority, and b) certain social structures, such as bilingual education, ongoing immigration from Latin America, and the socioeconomic position and cultural 
cache of some immigrant groups did not attach stigma to Spanish. Spanish has thus been an important language in South Florida for at least a half century, and some of its cultural influences have been mentioned previously.

This type of language contact situation is not unprecedented in the U.S. context, as has been described by sociolinguists and dialectologists previously. For example, work on the Pennsylvania German area suggests various phonological, lexical and morphosyntactic influence from German on English in the area (Kurath 1949) (Atwood 1953) (Kurath and McDavid 1961). Further, Purnell, Salmons, and Tepeli (2005) outline some morphosyntactic influence from German and Scandinavian languages along with other influences such as final stop devoicing in the Minnesota and adjacent areas. Also, Native American varieties have exerted influence on the New Mexico Pueblo English and Cherokee English in those areas (Leap 1993).

Due to historical language contact of diverse ethno-linguistic communities, sociolinguists have documented the substrate influence of various languages on the formation of dialects in numerous ethno-regional settings throughout the United States (Ma and Herasimchuk 1971). This literature shows that while phonological and grammatical influences from languages other than English may be instantiated as durable dialect features, lexical phenomena, including loan words and lexico-semantic calques, often fade over time as ethno-linguistic communities assimilate with contiguous dialect groups (McDowell and McRae 1972) (Galindo 1988) (Santa Ana, Otto, Bayley 1994) (Thomas 2001). However, in our preliminary investigations of emerging Miami 
Latino English, we have observed that lexical calques based on Spanish expressions are not only ubiquitous among immigrants but also extend into the speech of the second generation. Indeed, lexical phenomena appear to be a distinctive and enduring feature of the variety of English emerging among South Florida Latinos.

Both informally and in casual observation and formally in the analysis of our field data, we have observed a range of Spanish-origin lexico-semantic phenomena or calques in the speech of Miami-born Latinos. Examples include: 'get down from the car' instead of 'get out of the car', 'he invited me to a beer' instead of 'he treated me to a beer' and 'Marta recommended me this movie' in place of 'Marta recommended this movie (to me)'. This situation raises important questions for dialectologists, sociolinguists and other scholars interested in tracking the speech varieties emerging from South Florida's unique socio-demographic context. First, how ephemeral are the Spanish-influenced lexical phenomena we have observed? Do they hold in systematic ways beyond the immigrant generation? If so, are there changes in frequency of use or changes in intended meaning? Are new innovations present in the second generation that are not present among immigrants? Are these lexical phenomena appearing in other ethno-linguistic communities apart from the Cuban community as well?

For this research, we begin to approach answers to these questions with the first systematic, experimental study of the Miami English lexicon, which is intended to complement the corpus of sociolinguistic interviews currently being 
conducted and the related analysis of Spanish substrate influence on the phonology and grammar of English in South Florida. To test the durability of the Spanish influenced lexicon of Miami Latino English a unique translation task was designed, which will be described further. Additionally, five sociolinguistic interviews from the corpus have been included in this research to demonstrate some of the lexico-semantic phenomena tested in our experiment task in informal conversation. Further, the sociolinguistic interviews provided insights on additional phenomena that were not captured in the translation task. Together the translation task and sociolinguistic interviews give a clearer understanding of what expressions are commonly used, to what frequency they are used and by whom use them.

In order to answer our question about the durability of calques in Miami English, thirty-one participants were recruited in three groups: thirteen first generation Cuban Americans who were born in Cuba and immigrated to Miami as adults and twelve second generation Cuban Americans born and raised in Miami. The third group consists of six Non-Cuban Hispanics: four first generation participants and two second generation participants. Two of the first generation participants are from Venezuela, one is from Costa Rica and the fourth from Ecuador. The second generation Non-Cuban participants are of Guatemalan and Venezuelan descent. The third group of Non-Cuban participants was collected to compare if other dialects of Spanish bilinguals were using these expressions to understand if this was a phenomena happening mostly in the Cuban community or outside of it as well. Most of our 
second generation participants were recruited on local college campuses, while first generation Cuban participants were recruited in Little Havana, a well-known Cuban American neighborhood in Miami. To ensure both groups were bilingual in Spanish and English, I asked each participant, where they were born, if they were bilingual and how often and with whom they spoke Spanish and English. Thus, this research will add to the data on this emerging variant in the South Florida region by providing data on the variant's lexicon.

Cuban first and second generations were the preferred group to work with as their history with Miami expands longer than other ethnolinguistic communities in the region. Apart from their longer presence in South Florida, the Cuban community is the largest influence in the community, in education, government and politics, as will be described in further detail in the coming section. Thus, it seemed only right to start with the most influential group of Latinos in South Florida.

\subsection{Miami's History}

In order to understand the maintenance of certain Spanish to English phenomena in the Miami lexicon, it's vital to understand Miami's past and present influence and maintenance of Spanish. The influence and maintenance of Spanish of Miami-Dade County residences is due to in part the continued 63 year immigration of Cubans from the island to the Miami area. Prior to the beginning of immigration of Cubans to the region in 1959, Miami was just another predominately Anglo-White city in the Southeast. Census data in 1960 shows that the Cuban population was only around $4 \%$ compared to the $81 \%$ 
Anglo-white majority and the $15 \%$ African American population. The influx of Cuban immigrants to the city, would set the stage for other waves of immigrants from places like Nicaragua, Colombia and Venezuela, who were going through similar instances of economic hardship and political oppression; not to mention many others from Spanish-speaking countries, which by 2010, demonstrated that Miami-Dade County was about 64\% Hispanic/Latino (Carter, Lynch 2015).

Otheguy, García and Roca (2000) describe the four waves of Cuban immigration to South Florida in Speaking Cuban; the first wave consisted of 248,070 Cuban refugees and lasted from 1959 until the missile crisis of 1962. This first wave of refugees were mostly white and well-educated. These refugees under the Cuban Refugee Program established by the Kennedy administration, were given resettlement services, food, clothing and loans. Amidst the first and second waves was a smaller arrival of about 56,000 Cubans between 1962 and 1965. Along with this smaller arrival of refugees, another 6,000 Cubans settled who were released prisoners and their families from the Bay of Pigs operation. Further in the year of 1965, the Cuban government announced that it would allow Cubans in the US to collect other family members from Cuba. This operation that carried the second wave of Cuban immigrants later became known as the Freedom Flights. The Flights picked up around 302,000 Cuban family members and brought them back to Florida until 1973. After the Freedom Flights only about 50,000 Cubans immigrated to the region mostly through other countries. Between 1973 and 1980, an additional arrival of about 50,000 Cubans entered South Florida. 
Finally, the third wave of Cubans consisted of thousands who sought refuge from the Castro government at the Peruvian Embassy in 1980. These 125,000 refugees were granted the capability to leave Cuba from Mariel harbor in Havana in this same year. The final wave of Cubans to disembark, have been called balseros, as this group of 37,000 traveled by make-shift rafts from Cuba to Miami in 1994. However, in 1995, to prevent more balersos from entering South Florida, the US and Cuba agreed that the US would admit 20,000 Cuban immigrants a year for an unspecified period of time (Otheguy, García, Roca 2000).

As inferred in the history of immigration of Cubans to South Florida, the influx of Spanish speakers has created an environment in South Florida where Spanish plays a dominant role. This steady continuance immigration from Cuba has maintained an environment where most residents are monolingual Spanish speakers thus, Spanish became the primary language of Miami. However, as more residents found it also necessary to speak English, a bilingual Spanish and English academy was founded in South Florida. In 1963, the first bilingual academy was established in Coral Gables, called the Coral Way Bilingual K-8 Center. The establishment of this academy attests to the beginning of a bilingual environment in South Florida and need to learn English but also to maintain Spanish. According to Otheguy, García and Roca (2000), English monolingualism is not the linguistic goal in this bilingual U.S. city, where schools and business promote bilingualism as a preferred goal. Thus, again, it is observed that the maintenance of Spanish and bilingualism is encouraged. This 
is not to say that Spanish will be maintained for future generations, according to Fuller (2013), although Spanish may hold a high status in South Florida, Spanish may still fall below English in terms of overall status and the resources devoted to its promotion.

In addition to the steady immigration of Cubans to Miami, Spanish also has prevails due to the socioeconomic status of Cuban and Hispanic/Latino emigrants. These emigrants were educated and middle to upper class who departed their country because of the political situation; this situation is clearly different from the plight of many poor and uneducated emigrants who come to the US looking for a better opportunity in the agricultural, domestic or factory sectors. Further, Cuban Americans were and continue to this day to be highly engrossed in local, regional, and national politics, which gives them positioning as a powerful social group (Fuller 2013). As Fuller points out, the Cuban American community in Miami is quite a resourceful and a powerful body.

In comparison with other socioeconomic situations in other Hispanic populations in the US, the Cuban American community in Miami is quite particular. According to Silva-Corlaván (2004), in parts of the Southwest, as immigration from Mexico to the US increased, the quantity of people declaring Spanish as their home language increased according to 1990 Census data. The poorer and less well-educated counties include higher densities of Spanish speakers and higher retention, while the higher the educational and income status, the lower the index of language loyalty (Silva-Corlaván 2004). Further, Zentella (2004) notes the difficulties many Puerto Ricans encountered when 
they came to New York City. Puerto Ricans make up $36.5 \%$ of the 2 million Latinos living in New York City, according to 2000 census data. They are the largest group of Latinos on the island. Further, she describes that Puerto Ricans were confronted with discrimination in housing, education, health and the legal system and the scars from those battles are still seen. As noted, the situations of other assimilating Hispanic populations in the US, such as in the Mexicans in the Southwest and the Puerto Ricans in the Northeast are very different than those of the Southeast Cuban population. The Mexican and Puerto Rican Americans represent large communities in their particular regions and still are not able to be compared with Cuban Americans in respect to their high social, economic and political status in society.

Thus, the maintenance of Spanish in Miami, demonstrates the linguistic influence of Spanish on English in the area. Again, this influence of Spanish is quite unique if compared with other Hispanic communities in the US. Carter and Lynch (2015) point out that 'Unlike in other major U.S. cities, the prevalence of Spanish in Miami extends across all socioeconomic strata, as data indicated in the 2010 Census.' (pg. 8) Clearly, it is not the case that high levels of bilingualism in Miami are limited to only immigrant and working class neighborhoods. Thus the situation in Miami is quite unique as compared to the socioeconomic status of the speakers and Spanish in other parts of the US. Porcel (2006) states that 'Arguably, Miami Cubans might have greater incentives and the best conditions for language maintenance among all US Hispanics, but ....[t]he other position in this language equation, it should be 
remembered, is occupied by English, the language with more resources devoted to its promotion than any other language in the world.' (p. 107) As Porcel mentions, English may have the upper hand in terms of maintenance over time, thus, research such as this, will be fundamental in measuring how Spanish's influence over the lexicon of Miami English maintains and changes over periods of time.

\subsection{Other Research on Miami Latino English}

The sociolinguistic research on Miami's unique bilingual atmosphere is still developing if compared to other regions like the Southwest and Northeast. However, there have been a number of influential studies done regarding the description of phonological, syntactic, prosodic rhythm variants and vowel quality in Spanish and English, as well work in bilingualism and perceptual dialectology. This research in lexico-semantic phenomena complements the other work currently being done in Miami as it investigates the lexicon. The need for an integral description on Miami English and Spanish and their interactions is essential for a complete description of the region. The following section gives an overview of the current working being done in Miami and demonstrates how this research on the lexicon will complete the work being done.

Such work on Spanish in the region by Lynch (2009a) document dialect features of higher rates of sibilant /s/ retention among the young Miami-born third generation group in comparison to their immigrant grandparents who came to Miami from Cuba before 1980. The results found a reversed language change among the groups of Cuban Spanish speakers of Miami. Lynch's data credits a 
social need for the Miami-born Cuban Spanish speaking grandchildren of early exile Cubans to separate their speech to affiliate with more recently arrived Cubans, like the post-Mariel group, on political and ideological premises. The data showed that the rates of [s] sibilant retention among the Miami-born Cuban Spanish speakers versus the same age Marielitos group, which appeared to be the lowest. The rate of sibilant use among the highly fluent Miami-born speakers was much lower than that of the less fluent peers, but still slightly higher among the older generation of pre-1980 immigrants and more than double the rate found among young Marielitos. Thus, this trend can be attributed to a reversed language change due to the fact that sibilant weakening is an ongoing diachronic change familiar to Caribbean Spanish. (Carter, Lynch 2015) Alvord's (2010), findings displayed varying intonation patterns from contact with speakers of other varieties of Spanish in Miami. These findings present interesting questions for future research on dialect contact within Spanish varieties in Miami as well the progression of phonological evolution of Spanish in contact areas.

Work regarding English in Miami by Carter, López, and Sims (2014) understand a possible structural influence that Spanish exerts on English in Miami. The study consisted of twenty-one English speaking second generation Miami-born Latinos and five Anglo Whites to measure the phonetic variables of prosodic rhythm and the quality of the low front vowel /æ/ in pre-nasal and nonpre-nasal contexts. In the first instance, Latinos have been shown to produce more syllable-timed rhythm than non-Latinos, and for the second instance, Latinos have been shown to abstain from the termed 'allophonic split' (Thomas 
2011) in which /æ/ is raised before nasals but is unraised in other positions where a nasal is not following the vowel. Results were generated using the Pairwise Variability Index, which was developed by Low \& Grabe (1995) to quantify rhythm while at the same time controlling for speech rate. Results indicated that Miami-Latinos were significantly more syllable-timed than of the Anglo-White comparison group. Further, results for the /æ/ allophonic merger were unexpected for Latinos, as there was no merger for this group. However, vowel quality for both the pre- and postnasal allophones, was found to be lower and more back when compared to the higher and more front nature produced by the Anglo White group. Carter et. al (2014) notes, '..that although influence from Spanish seems to be a likely explanation for the pattern of prosodic rhythm found among Miami Latinos, more work is needed in order to understand the role of Spanish on the Miami Latino English vowel system.' (Carter, Lynch 2015)

Similar studies on phonetic analysis of the Miami Latino dialect Cerney (2009) and Dorenger, Cerney (2008) add to the overall foundation of knowledge building on several important descriptions of certain phonological and structural aspects of Miami Latino English, not to mention, similar projects regarding perceptual dialectology (Carter, Callesano 2014). Carter and Lynch (2013), in the form of matched-guise style study testing listener's implicit perceptions of English and Spanish (2013) and three varieties of Spanish (2014), plus additional bilingualism research, Garcia \& Otheguy (1988), Lopez- Morales (2003), Lynch (2000) and Roca (1991) who have all indicated the predominate status and high value of Spanish has incubated a prevailing bilingual speech community. 
One part of research that compliments the overall work being done in Miami is the description of the unique emerging lexicon in this region (Mullen 2014). As already mentioned, most work on language variation and dialectology often forgets the place that the lexicon holds as a feature of the vernacular. It is noted that lexical descriptions of a given vernacular is often left last for study due to the prominence for phonological and structural forms which can more often than not transform into durable dialectal features while the lexicon is noted often to fade over time as speech communities assimilate. In contrary to this stance, this research will investigate the lexico-semantic phenomena occurring in the South Florida region as it has been observed to be maintained, to such a degree 'passed down', from first Cuban Americans to second generation Cuban Americans.

This research aims to answer a series questions; first, how ephemeral are the Spanish-influenced lexical phenomena we have observed? Do they hold in systematic ways beyond the immigrant generation? These questions specifically seek to find out how the first and second generations are using these lexico-semantic phenomena; in the same or different ways? It could be possible that most of the observations are from the first generation in which one would expect more calqued expressions and lexico-semantic phenomena, this research seeks to answer that. If these phenomena hold in the second generation, are there changes in frequency of use or changes in intended meaning? Are new innovations present in the second generation that are not present among immigrants? Finally, a portion of this research will tap into other 
Latino communities in South Florida, apart from the Cuban community. This research will begin to give insight to help answer the question: Are these lexical phenomena appearing in other ethno-linguistic communities apart from the Cuban community as well?

The hypotheses based on casual observation is first and second generation Cuban and non-Cuban communities are using lexico-semantic phenomena. To what extend the usage is ephemeral is quite hard to hypothesize to a certain degree, however, due to the complex relationship of Spanish and English usage around the community, constant immigration to the region and a highly perceived socioeconomic status that Spanish holds, my stance is that utilization of several phenomena are still quite frequent among the second generation communities and have a very good chance of becoming a durable part of the lexicon. This work will intend on measuring the frequency of the selected lexcio-semantic data to find answers to these questions.

4.0 Methodology of this study

The selection of the lexico-semantic phenomena was derived from frequent observation of these forms in various settings across the South Florida/Miami community. Some of the phenomena such as super and expressions such as he invited me to a beer and recommended me this movie were observed on the Florida International Campus. Others such as 'give me a chance', 'get down from the car' and 'I want' were noted in various socioeconomic neighborhoods, like the financial district on Brickell Avenue and also in more humble neighborhoods like Little Havana. The high occurrence of 
these phenomena in these different settings across neighborhoods and also across generations influenced my curiosity and motivated me to study them in a systematic way. Thus, all of the lexico-semantic phenomena were collected from my observations around the community; in total, I collected fifteen words or expressions.

I organized the words and expressions into simple sentences in Spanish that would be easily translated into English as to not put too much mental effort on the participant to ensure the most authentic translation. The phenomena was folded into these sentences naturally as to not give any cues to the participants on what was being examined. I instructed the participants to read each sentence and translate them one-by-one aloud and instantaneously while I recorded them on a device. Before beginning the task, I asked the participants a couple of questions; first, are you bilingual? How often do you speak Spanish and with whom? If any participant did not identify as bilingual or did identify as bilingual but was not able to translate the sentence, their task was discarded and not counted. All of the participants that I used in this study identified as being bilingual and spoke both languages on an almost regular basis. The common response by many of the second generation participants was they often used more English than Spanish, when they used Spanish it was when speaking with a relative at home. The majority of the second generation participants also mentioned more of comfort with English than Spanish. The first generation participants expressed using Spanish slightly more than their 
second generation counterparts. They expressed using it in public, outside of the home and also at home quite frequently.

My participants were recruited on the Florida International University (FIU) campus and in these various neighborhoods like Brickell and Little Havana mentioned above. The second generation participants were mostly recruited on the FIU campus by simply asking various groups of students if they would like to participate in a study. The same was done for the first generation participants; they were asked if they wanted to participate in a study. Since the task only takes about five minutes to complete, many were willing to participate.

A number of the first generation participants were recruited at a local school in Brickell at which I was employed with on a part time basis. Others were recruited at the FIU campus and in the neighborhood of Little Havana, where I lived for a period of time. No compensation or benefit was given to the participants, they came freely and willingly to participate.

I explained to the participants that their names would not be used to identify them in this study. Further, I explained that their audio recordings would not be used if they so wished. None of my participants expressed concern about using their audio recordings nor did they wish their audio not be used in the presentation of this research.

I recruited thirty-three participants and divided them into three groups: fifteen first generation Cuban Americans who were born in Cuba and immigrated to Miami and twelve second generation Cuban Americans born and raised in Miami. The third group consists of six Non-Cuban Hispanics: four first 
generation participants and two second generation participants. Two of the first generation participants are from Venezuela, one is from Costa Rica and the fourth from Ecuador. The second generation Non-Cuban participants are of Guatemalan and Venezuelan descent. The third group of Non-Cuban participants was collected to compare if other dialects of Spanish bilinguals were calquing these expressions to understand if this was a phenomena happening mostly in the Cuban community or outside of it as well.

\subsection{Description of Task Statements}

A list of the Spanish test statements cuing possible Spanish-English lexico-semantic phenomena is shown below.

1. Marco y yo fuimos a un bar y me invitó a una cerveza.

2. Marta me recomienda esta película.

3. Estamos pensando en tener la fiesta en la playa e invitamos nuestros amigos.

4. Carmen se casó con Antonio y gracias a dios no llovió.

5. Jorge le preguntó a Silva, ¿"Quieres comprar fruta?" "Sí, quiero."

6. Vamos a hacer una fiesta para mi amiga María.

7. Bajamos del coche y entramos en el supermercado para comprar comida.

8. José no podía ver nada y le dijo a Martín, "Pon la luz, Martín!"'

9. Jessica compró un vestido elegante. Tiramos una foto de ella y su vestido.

10. María fue a una cafetería y compró un café y una empanada de carne.

11. ¿Puedo ir a tu oficina mañana?

12. Era más una discoteca que un bar, porque era super grande con la música demasiado alta, no podíamos hablar. 
13. Pedro gritó al conductor, "Dame un chance, por favor", cuando cruzaba la calle.

The following are the English translations. As shown, these lexical expressions noticeably vary from the variety we might call Standard American English.

1. Marco and I went to a bar and he invited me to a beer.

2. Marta recommended me this movie.

3. We are thinking in having a party in the beach, we can invite our friends.

4. Carmen married with Antonio and thanks god that it didn't rain.

5. Jorge asked Silva, "Do you want to buy fruit?" "Yes, I want".

6. We are going to make a party for my friend Maria.

7. We got down from the car and entered the super market for buy food.

8. Jose couldn't see anything and he told Martin, "Put the light, Martin!"

9. Jessica bought an elegant dress. We threw a photo of her and her dress.

10. Maria went to the cafeteria and bought a coffee and a meat empanada.

11. Can I go to your office tomorrow?

12. It was more a club than a bar, because it was super big with the music too loud, we couldn't talk.

13. Pedro shouted at the driver, "Give me a chance, please" as he crossed the street.

Three lexico-semantic phenomena are worth explaining a bit more in detail. The phrase, 'can I go to your office tomorrow' (\#11), comes from a deictic difference between Spanish and English. The motion verbs go and come can be used differently in both the languages. For example, in English, it's noted that SAE variety speakers would normally use come, shifting the deictic center from the speaker to the addressee, where a Spanish speaker would use go for 
these certain expressions (Huang 2007). In Spanish, normally, there is no shift, therefore, as supposed, Miami English reflects more of a Spanish deictic construction.

The following calques like 'super' and 'dame un chance' wholly or partly originate from English and are already common words or phrases in Cuban Spanish and have been established as part of the Cuban Spanish lexicon.

However, they are still calqued into the Miami English vocabulary as they are semantically different from Standard American English. For example, super, in SAE, is normally used as an adjective to describe something that is excellent, outstanding, great or terrific. However, in Miami English, super is the preferred word, used as an adverb in place of really, very and so. For example, 'It was a super big car.' Alberdi-Larizgoitia (2010) states that '....the mechanism of a semantic calque triggers semantic widening or semantic change. Thus the meaning of an inherited word in the target language is extended by addition of a new meaning that belongs to a corresponding word in a source language.'(pg. 22) Thus, super, already being calqued from the English super, has widened semantically and adopted a new meaning, as we see with this example. Further stated by Maria in our sociolinguistic interview, when asked what some things that people say in Miami are, she responded by saying:

@19:19 “....super, super is like a Miami thing...”

Thus, super may indeed have semantically widened, originating from English calqued into Spanish and then calqued and widened back into English, 
and now has become part of the Miami English lexicon and is semantically distinct from a standard interpretation.

Additionally, 'dame un chance' or 'give me a chance' is also worth mention. Although chance, an English word is used in this expression, it is a frequently used expression of Cuban and Non-Cuban Spanish speakers. Again, the word chance here mimics the widening that of super, as it originates from English but has semantically changed over time in the Spanish lexicon. This expression has also been transformed into the calque: give me a chance. This calque, based on personal experience, can be used in situations where it may be used in SAE English but it is more commonly used when crossing the street or when a person is trying to ask for permission to move from one location to the next while crossing another person's path. Thus, this expression may semantically and pragmatically differ at times from the SAE variety.

Other phenomena, such as 1-9 excluding number 2 can be categorized as literal lexical calques as oppose to semantic calques as the literal lexical calques adhere the most accurately to the model [language] by translating each of its components exactly; each morpheme of the model [language] is translated using the closet equivalent morpheme In the target language. (Lewandowski, 1990) As in the first calque, 'he invited me to a beer', is literally translated from the Spanish verb 'invitar', which as noted semantically and perhaps pragmatically varies from how it is used in English. In Spanish, the verb is used in a variety of ways, inviting someone over to your house, like in English, is one meaning, however in Spanish 'invitar' also means to 'treat', and 
as noted in English, the 'invite' is more limited semantically than in Spanish. This is the same for numbers 1-9 except number 2. Number 2, 'Marta recommended me this movie' from 'Marta me recomienda esta película' in Spanish, is classified as a lexical calque, as the internal structure is copied from the source language into the target language.

Lastly, number 11, 'meat' from 'carne', like 'invite' from 'invitar', prompts participants to make choice between different semantic options in the source language to the target language. 'Carne' in Spanish has more entries than in English. For example, 'carne' in Spanish refers to both meat and beef, the meaning of the term will depend on the context, but only one representative form is utilized. In English, there are two different forms which adhere to the context and additionally carry further significance. One knows that in English meat is usually referred to as uncooked parts of animals, where beef is more specific to cooked pieces of cow. Thus, the participant is forced to choose between two different lexical entries in English when only one exists in Spanish for these general terms.

The task was designed to indicate Spanish's impact on English in South Florida by documenting well known lexico-semantic phenomena and their transcendence and adaptability onto the younger generation of Cuban and Hispanic Americans. Additionally, it is hypothesized that certain phenomena were transmitted from older first generation Cuban Americans and are now residing within the English lexicon of the second generation Cuban Americans. This may also be the case with the Non-Cuban generations as well, additional 
participants will need to be collected in order to analyze how they may be saying these expressions the same or distinctly from the Cuban community. Since the growing immigration from Latin America is not only coming from Cuba, other Hispanics may also be influencing the Miami English lexicon. What can be said at this time is that this research is distinctive in the fact that most research on calques, code-switching and loan words in the US has been done in the Northeast and Southwest and on how English affects Spanish. This research on Spanish-to-English phenomena in the Southeast demonstrates the effect that Spanish has on English in Miami.

\subsection{Results}

This chapter will be dedicated to the results and the explanation of those results of the translation task experiment. Our overall findings show that both groups - the first and second generations - continue to utilize certain of the tested expressions. Although some of the expressions remain in the speech of the second generation, we note a general quantitative decrease from the first immigrant generation to the second generation Miami born participants. Curiously, other calques such as, 'meat' are being used for translations of 'beef'. For example, a meat empanada versus a beef empanada. Deictic verbs such as go and come reflected more of a Spanish influenced usage than an SAE usage. Further, the Spanish derived expression 'give me a chance' was maintained with the second generation more than with the first. These were all demonstrated to be utilized more with the second generation rather than with the first generation. Therefore, as we observed a decline in frequency in certain 
constructions in the second generation, we have also observed that they have increased in frequency in other constructions.

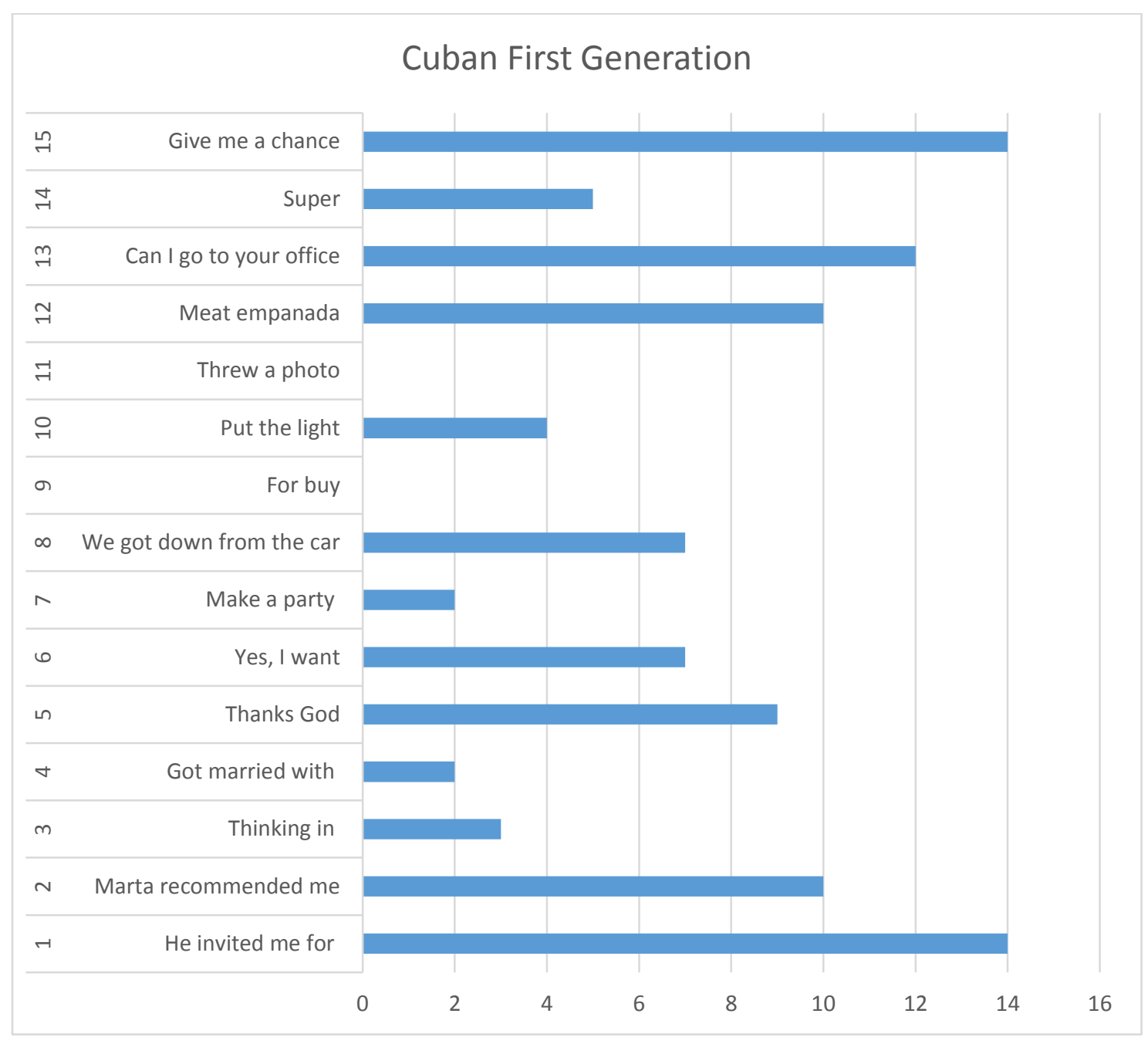

Figure 1 


\subsection{First Generation Cuban Americans}

Figure 1 displays the frequency of each lexico-semantic phenomena's occurrence for the first generation. The frequency of each occurrence is listed hortizonally while each phenomena's assigned number is listed vertically. As shown, of the fifteen participants the most frequently occuring phenomena appeared to be with the phrase, 'dame un chance to give me a chance' (\#15) and 'me invitó a una cerveza' (\#1). Fourteen of the fifteen or $93 \%$ of the participants used these phrases to 'give me a chance' and 'he invited me to a beer.' One of the participants translated this sentence to 'he invited me for a beer', which we included as Spanish influenced in our tabulation, but may deserve further thought.

The next most frequent phrases were 'meat empanada' (\#12) and 'can I got to your office?' (\#13). Ten of the fifteen or $66 \%$ of participants used a more Spanish influenced rather than Standard English influenced constructions by saying a 'meat empanada' instead of a 'beef empanada-' The meat empanada example may have translated this way in part to the usage of 'carne' in Spanish as it is one word that is used to signify meat or beef. In English, we know that meat is a more general term, usually said when referring to uncooked pieces of various animals. But that beef is more specific to cow meat that has been cooked. Therefore, a SAE variety speaker, would normally ask for a beef empanada rather than a 'meat empanada.'

Number 13, 'Can I go to your office?' rather than 'can I come to your office?' was calqued by twelve out of the fifteen or by $80 \%$ of participants. It's 
note worthy that for two of the participants used the verb come instead of the verb go for this construction, so even though, the verb ir was used in the statement, two participants preferred the verb come. Using the verb come instead of the verb go, shifts the deitic center from the speaker, which is common in varieties that mirror SAE (Huang 2007). Additionally, one participant used an alternative expression, 'stop by' for their construction.

Others such as 'thanks God', 'Marta recommends me' and 'get down from the car' are also noteworthy. Ten out of the fifteen or $66 \%$ of participants translated the sentence, 'Marta me recomienda esta pelicula' (\#2) to 'Marta recommends me this movie', instead of 'Marta recommended this movie to me', or 'Marta recommends this movie.' Further, 'thanks God' (\#5) was expressed by nine or $60 \%$ of participants to 'thanks God' or the alternate, 'thanks to God.' Two of the participants used, thanks to God as their translation, the remaining six used 'thanks God.' Only one participant used 'get down from the car' for 'bajar del carro' (\#8), while the other remaining six participants used 'get off of the car' as their translation. Two participants used 'came out of the car' and 'went out of the car' as their translation, still distinct from an SAE usage. Thus, $46 \%$ of participants utilized this form. Further, the expression 'Yes, I want' (\#6) instead of 'Yes, I do' was translated as such by seven or $46 \%$ of participants. Others who did not used this translation of 'Yes, I want', used a more SAE construction like 'Yes, I do' or 'Yes, I would.' Finally, it should be noted that although two of the participants from this first generation, did not use 'super' (\#14) in the translation task, I observed them to use super as an adverb in 
English in the brief conversation I had with them before and after the task. It is therefore possible that the task itself induced a certain reluctance to use lexicosemantic constructions that speakers may perceive as stigmatized in formal contexts.

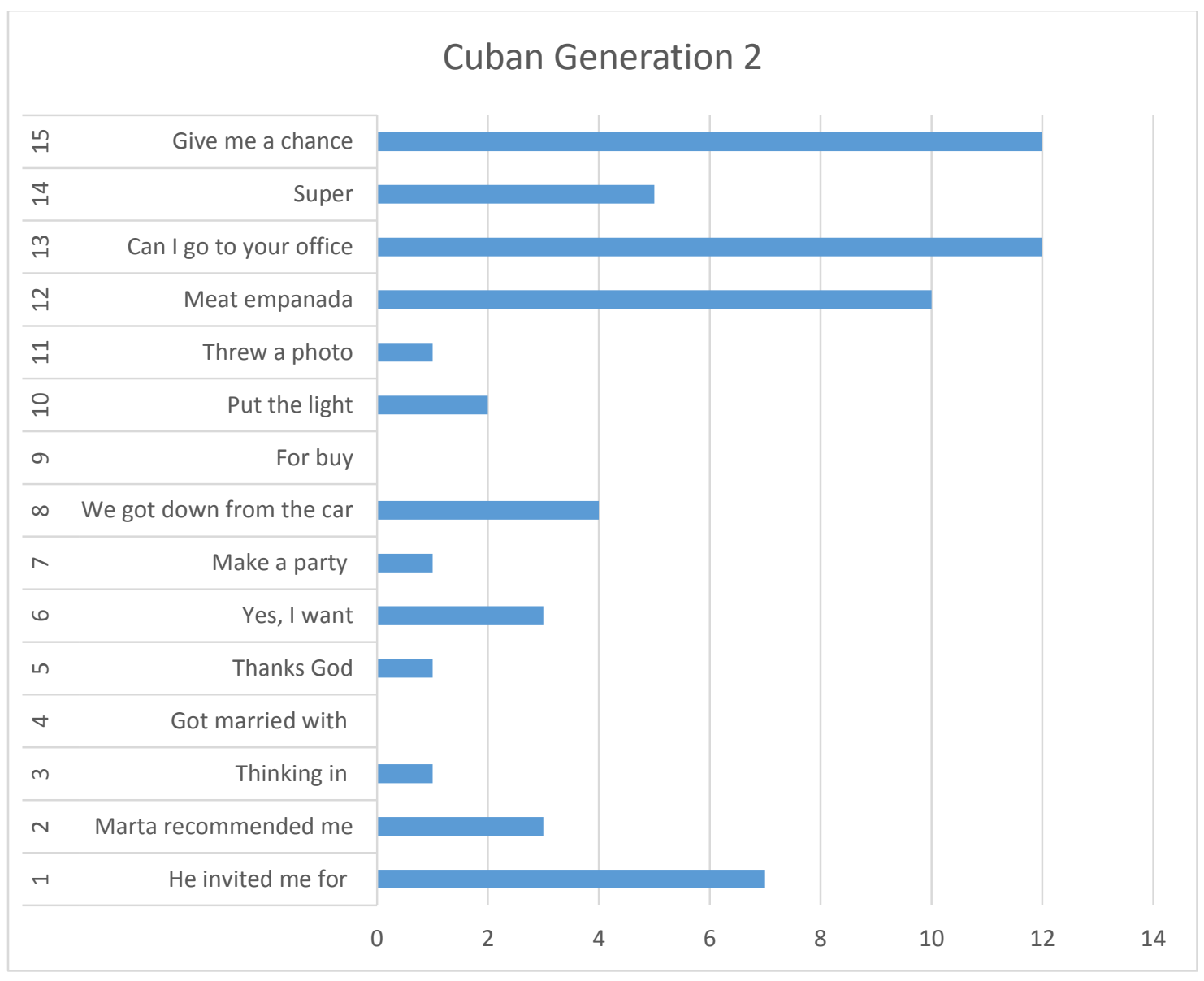

Figure 2 


\subsection{Second Generation Cuban Americans}

The results from the second generation show that there are some similarities with the prior generation, although there appears to be a marked decrease in frequency in this generation. The figure 2 shows that the three expressions that were most frequently provided are 'meat empanada' instead of 'beef empanada' (\#12) at 83\%, 'can I go to your office?' instead of 'can I come to your office?' (\#13), and 'give me a chance' (\#15) both at 100\% use. Further, the expression 'he invited me to a beer' (\#1) instead of 'he treated me to a beer' or 'he offered me a beer', requires some additional unpacking as well. Rather than using the construction, 'he invited me to a beer', four or $33 \%$ of the participants used an alternative construction: 'he invited me for a beer.' The other three participants used 'he invited me to a beer' as most of their first generation counterparts had. One participant translated this construction to 'he treated me to a beer', which mimics more of a SAE translation. The others who hadn't used this construction used alternative translations such as, 'he bought you a beer'.

Lastly, as noteworthy, this second generation translated the sentence 'Era más una discoteca que un bar porque era super grande...'(\#14), to 'It was more a club than a bar because it was super big...', instead of a more SAE construction of 'It was more a club than a bar because it was really/so/very big.' This translation was used by five out of the twelve or $42 \%$ of participants whereas the first generation's participants translated this expression four times out of fifteen or $26 \%$ of the time. 


\subsection{Comparison of Both Cuban American Generations}

The next figure has been constructed to show a comparison between the first generation and second generation.

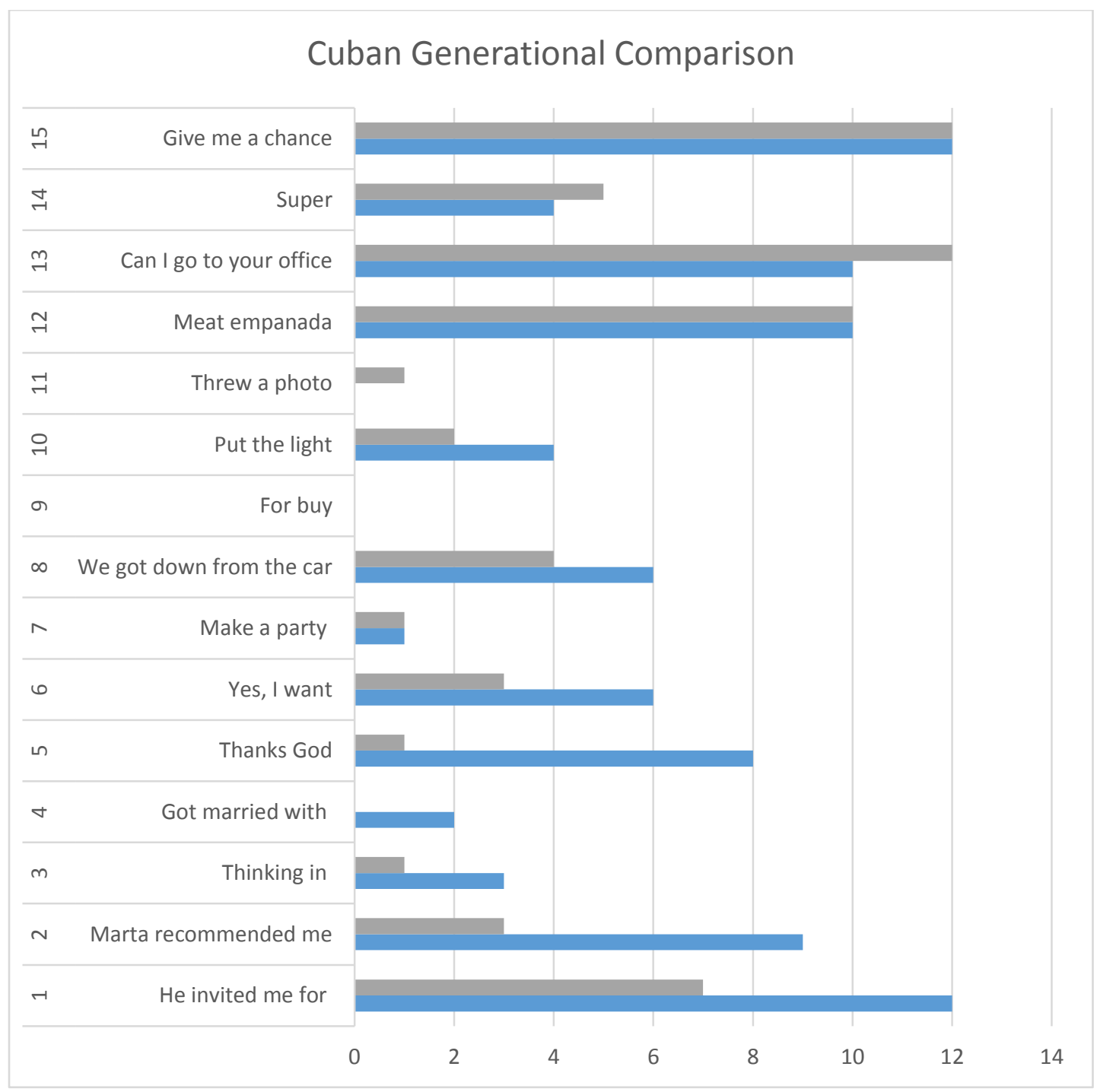

Figure 3

First generation in Blue and second generation in Grey 
Major differences between the maintenience of certain phenomena appear mostly to the left of the figure. As shown, certain expressions still appear to be maintained with the second generation. The first, "he invited me to a beer ' does show that there is still some maintenance with this expression by as more than half, $58 \%$, of the second generation used this expression or a similar one in their translations. Further, number 8 , shows that some of the second generation are maintaining the expression, 'get down from the car' or one its alternatives like 'get off the car' as $58 \%$ or seven out of the twelve participants use the expression more than their first generation cohorts, which show only four out of the fifteen or $26 \%$ of the participants using this expression.

Additionally, number 12 'carne' translated to 'meat', number 13, 'can I go to your office?' and number 15, 'give me a chance', appear to be used at the same frequency or more among second generation than with the first. The usages between number 12 'carne' to 'meat' and number 13 'can I go to your office?', is very interesting and deserves consideration; other factors may have influenced these usages, such as if these particular second generation participants' parents or other adult members of their community also maintain usage of these forms in their personal lexicon or if these forms have been accepted among the second generation as the standard apart from their parent's and other community member's ultization of the forms. 
Number 14, 'super' is also of particular interest, as almost half of the second generation used this expression in their translation while the first generation's usage was less than half. This expression's frequency was not surprising, as we have observed a high usage of 'super' in our field observations, in place of other adverbs by the second generation.

Lastly, number 9, 'we went to the supermarket for buy food' also deserves mention as it was not utilized by any of the participants in the study. It's possible to conclude that the decrease between the utilization of these forms from the first generation to the second, could be from the presence of unbalanced bilinguals in the first generation's study. That is to say those still engaged in the process of learning English and thus is no longer used by natives or those equally fluent in Spanish and English. Additional research will need to be carried out in order to investigate these other perhaps underlying factors. 


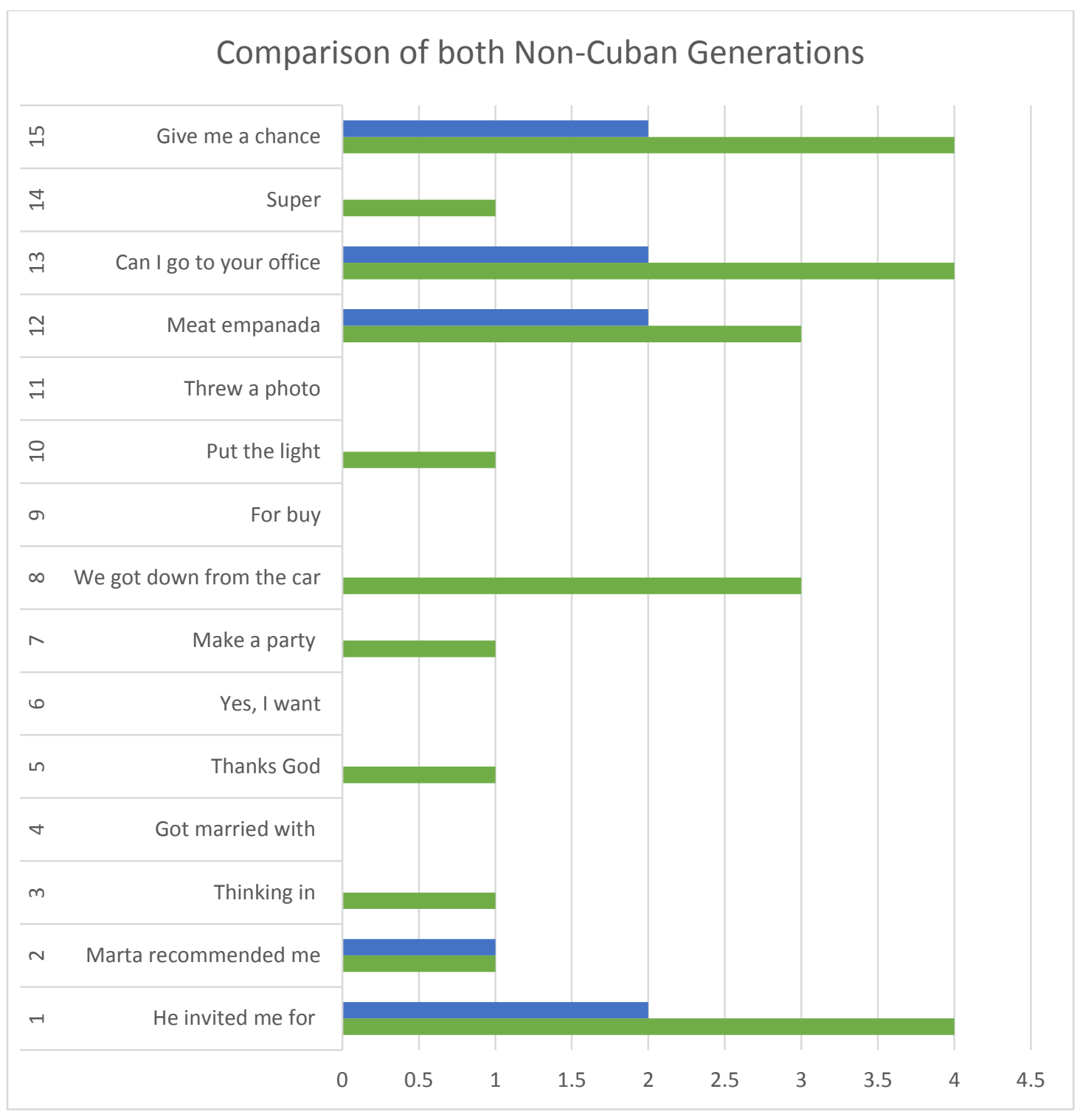

Figure 4

First generation in green and second generation in blue 


\subsection{Non-Cuban Latinos}

The final figure, figure 4 , shows preliminary results of a small group of Non-Cuban Latinos. Of the group, four participants were first generation Latinos from Costa Rica, two participants from Venezuela and one from Ecuador. The second generation group consisted of two members, one from Guatemala and the other from Venezuela. From a first glance, it can be noted that the first generation Non-Cuban Latinos used more lexico-semantic phenomena than the second generation. However, for four translations, both groups translated certain expressions at the same or at almost the same frequency.

Number 1, 'he invited me to a beer', number 12, 'carne' to 'meat', number 13, 'can I go to your office?', and number 15, 'give me a chance', were all translated the same by all participants or $100 \%$ of the time in both generations at the same frequency with one exception, number 12, 'carne' to 'meat', was translated to this form for three out of the four or $75 \%$ of participants for the first generation versus two out of two or $100 \%$ of participants for the second generation.

Additionally, the phenomena that the first generation translated three out of the four possibilities that the second generation had used at all was number 8, 'get down from the car'. Three out of the four first generation participants used the expression 'get down from the car', while the fourth participant from Ecuador, used the expression, 'go out of the car'. Although, this translation does very slightly from a SAE translation, it wasn't exactly similar enough to the get down translation and thus was not counted as a phenomena for this study. 
This participant may have produced this translation due to the configuration and/or constraints of the translation task, more participants for this Non-Cuban study will be needed to calculate any significant difference in translation of this statement between Cubans and Non-Cubans.

Finally, when comparing the two groups as a whole: First and Second Generation Cubans to the First and Second Generation Non-Cubans, a similar pattern arises between both figures. Both figures 3 and 4 include higher frequencies of lexico-semantic expressions on the ends of the both figures, meaning both groups as a whole are using the same expressions for: he invited me to a beer' (\#1), 'carne' to 'meat' (\#12), 'can I go to your office tomorrow?'(\#13) and 'give me a chance' (\#15). The entire Cuban group's frequency as noted by the chart as almost $100 \%$ for each of these previously mentioned phenomena. The Non-Cuban group follows that similar pattern by using those expressions in a similar fashion, at almost $100 \%$ frequency for all participants in both generations. The noted difference between the two is number 1, 'he invited me to a beer', as the Cuban second generation stray a bit from this overall comparison as 7 out of the 12 or $58 \%$ of participants expressed a lexico-semantic phenomena, while the remaining 5 used alternative expressions such as 'treat me' or 'offered me'.

As both groups appeared to have similar trends; the first generations used lexico-semantic phenomena more frequently overall than the second generations and both generations appearing to have a higher frequency of those expressions at the beginning and end of the figure, one significant 
difference between both groups, is with number 14, 'super'. Although both groups translated this expression at relatively lower frequencies (Cuban 4:5 or $80 \%$, Non-Cuban $1: 0$ or $50 \%$ ), it's interesting that more second generation Cuban Americans had used 'super' in their translation of the statement, 'it was more club than a bar, because it was super big, with the music too loud, we couldn't talk', in place of an adverb such as really, so and very. As most of the participants preferred to use these adverbs, especially, the first and second generation Non-Cubans, the second generation Cubans display a slight preference for 'super' in their translations versus the other groups.

Lastly, another significant finding is that the second generation NonCuban group lacked overall high frequencies if any frequencies for most of the translations, especially in the middle of the chart. More participants will be needed to determine any significant decreases in phenomena from this group.

\subsection{Discussion}

As demonstrated by this preliminary analysis on lexico-semantic phenomena in the Miami-Dade area, certain phenomena have become part of not only the first generation's but also the second generation's lexicon for both the Non-Cuban and Cuban groups. However, as shown in the previous charts there does appear to be a decline overall in the second generation's maintenance of some expressions. Various factors could account for the loss of these expressions. One factor may be education; all of these second generation Cuban Americans and Non-Cuban Americans were born in Miami and therefore 
had received their education in English, which would expose them early on to 'Standard American English'. As mentioned previously, most first generation Cubans and Non-Cuban Hispanics were either monolingual Spanish speakers or came from monolingual households upon arrival to Miami and had to learn English in different ways, that is to say the majority of them did not receive their elementary and high school education in the US. This difference of English education and immersion could be a reason as to why certain phenomena have been less acquired by the second generation of Cuban Americans and NonCuban Hispanics.

Although this study is preliminary, this examination of the maintenance of certain lexico-semantic phenomena from first generations to second generations demonstrates the impact that Spanish has on the Miami English lexicon. Further research is needed to understand the extent to which these types of expressions are used by national-origin groups other than Cubans and to understand the way these expressions are perceived vis-a-vis their Standard equivalents. And, as ever, more data and more participants are needed; we hope to rerun this study with a larger subject pool as we continue our study of the Miami English lexicon.

6.0 Sociolinguistic interviews

Although these findings are interesting and enriching in the lexicon of Miami English, the nature of spontaneous task experiments is not able to test the durability of lexico-semantic phenomena in Miami. To complement the 
findings of the task experiment, sociolinguistic interviews will be utilized to identify the phenomena as well. A variety of sociolinguistic interviews were conducted on the Florida International Campus and this section will be dedicated to the findings and discussions of five selections of the corpus.

All participants used have chosen pseudonyms in place of their actual names. All were born in Miami and are second generation Cuban Americans minus one, Alex HM's parents are from Peru. Further, all participants note that English rather than Spanish is their preferred language, as the common discourse surrounding all the participants was that they felt more comfortable speaking in English. These statements attest to the hypothesis that the phenomena are part of the Miami English lexicon which is spoken by those second generation speakers fluent in English rather than in Spanish.

The following detailed reviews of the interviews provide the complicated bilingual landscape that these participants maneuver, not only in public places around Miami but also in their homes, among family members. Not all the phenomena formulated in the experiment task were utilized by the interviewees; however, other phenomena were noted. Ongoing analysis will be needed to understand the durability of the phenomena found in these interviews.

Further, these selected interviews formulate further questions regarding how these phenomena originated, such as: Did they form through the constant interplay of Spanish and English spoken at home and in public? Or, were these expressions taught through schooling by teachers or parents who 
also used the phenomena? Further study will be needed to answer these questions regarding the origin of these expressions.

\subsection{Maria}

Maria is a first generation Cuban American who came to the United States at the age of three. As mentioned in a previous section, Maria's answer of 'Super, super is a Miami thing' @9:19 to the question 'What are some things that people in Miami say?' attests to the high usage of super in Miami as we have seen on the previous charts. Additionally, Maria stated 'super' in this way in her interview when describing her high school experience:

@9:54 “....I was super smart but super cool at the same time ...'

Maria is usage of the term super as an adverb in place of really/so/very shows such as a semantic calque, which is perceived as widened, or change/expand its significance when calqued from the source language to the targeted language (Alberdi Larizgoitia 2010). Thus, 'super', through the task experiment data and through this naturalistic data and appears to have semantically widened from Spanish to English from an adjective such as 'great' as in the statement, 'great job', to an adverb in Miami English to mean really/so/very.

Maria additionally stated two other possible phenomena:

@24:34 “...The city [Miami] is so rich and like so much to offer..." 
This statement is very similar to the Spanish expression rico or rich, but not meaning rich as in money, as it appears Maria is using rich and she would use it in Spanish to describe something darling, great, possibly full or abundant [of something] as the term rico in Spanish is used in this way and in English rich would not be normally used to describe something like this.

@36:46 "They had a lot of luck with jobs and just with opportunities"

This statement is a calqued expression from the Spanish expression tener suerte, which literally means to have luck, when it would be normally expressed as to be lucky as in they were lucky in place of they had a lot of luck. Maria used this expression when she described her parents coming to the United States and becoming successful here.

Maria also provided other details of expressions and lexical items that are unique to Miami when responding to the question: what are some things that people say in Miami that they wouldn't say in Tennessee or Boston?

@19:04 "Supposedly, like I feel like people, like even though supposedly is a word, I feel like we over use it in Miami... like supposedly this person said this, no one talks like that anywhere else.."

@19:13"...For sure, like for sure, people don't say for sure.."

@19:19"...Super, super is like a Miami thing..." 
@19:26 “...Like, I feel like, like is in your vocabulary and other people don't speak that way....and I think I learned this from the guy I was with, like he didn't speak, like I feel like he, like omg, like you really don't speak like me at all.."

@19:36 “...ummm...Literally..”

Maria stated that she has lived in other parts of the United States, in places such as Tampa, Orlando, North Carolina and Tennessee:

@14:20 “...if you go to Tampa, Orlando, North Carolina, which l've been Tennessee which I've spent a lot of time when I was little."

She realized that apart from the lifestyle in Miami, she also noted that she spoke differently phonetically when describing language in Miami:

@17:25 “...I thought I spoke English perfectly before, like when I was like fourteen, then I like traveled to Tennessee for the first time, I mean I guess I had always traveled there, but when I was fourteen I realized that, someone was like, oh but you're like, you're like you know, from Miami, you're from, you're like Hispanic and I'm like how can you tell? [Maria] What do you mean? [other person] you're accent is SO strong [other person]. I'm like really? [Maria] They're like ya, really strong. And then like in Miami everybody speaks the same...."

These statements both regarding the lexicon and the phonetic differences, (i.e. @17:44 “...you're accent is So strong...”) attest to the uniqueness of the unique features of this Miami dialect both lexically and 
phonetically. Further, this interview and the task experiment together have verified the usage of the term super as calque occurring in this unique emerging dialect.

Additionally, Maria, expresses the complexity of using Spanish and English in various interactions in Miami when asked the questions, Do you mix languages?

@22:14 "Umm, ya but I do it with certain people, like with my mom, I'm always speaking, like it's the code-switching, I always code-switch with her, my [unintelligible] friends that I have that may be don't speak English so well, I code-switch them, because it's hard for me to express myself in Spanish, even though it's my first language, I guess it's difficult for me to get my point across in Spanish, so l'll code-switch with them..."

@ 22:51 "My boyfriend and me, we don't speak in Spanish, I don't think we ever say a word in Spanish to each other, EVER, in like the whole time we've been together, I don't think we've ever spoken a word of Spanish together....and me and my close friends either, we don't speak Spanish to each other at all, unless it's like a joke or you see something and read it...but we don't speak Spanish at all.."

Statements like these attest to the complexity of the language choices in social situations in Miami in which speakers interact in one or both languages and how speakers like Maria, even though state that they are native speakers of Spanish, prefer to speak English. Thus, speakers like her, should not be counted as 'non-native' speakers of English, but in fact native or balanced, and 
also that these phenomena are originating from native or balanced English and Spanish speakers in complex language interactions.

6.2 SS

SS is a second generation Miami born Cuban American. Like most second generation Cuban Americans, she demonstrates a trend like most of the second generation that is observed in Miami; bilingual in Spanish and English, but a preference for English. Most bilingual speakers of the second generation, like SS, express a preference for English when asked the question: Show when do you feel when you use Spanish? With your family? Are there any other social situations where you would use Spanish?

@24:48 “...I have some friends that prefer to speak in Spanish than in English, so, I don't know why they do, I personally, don't feel comfortable speaking in Spanish, if I know you speak English...there's only a few friends that do that [prefer to speak Spanish] I don't see it, I don't get it, it's one of those things that surprising me, it's very few friends that do that...then sometimes will switch from a totally English conversation to a Spanish one"

But you feel more comfortable in English?

@25:41 "Definitely. I feel like sometimes when I speak Spanish, the first thing people notice is my accent...I get really conscious about it sometimes"

@26:00 “...But when I go to different places like grocery stores, like Publix, you have to speak in Spanish.." 
Do feel like there's a lot of Spanish on campus or you do mostly not use your Spanish on Campus?

@26:58 “I usually never use my Spanish on campus unless I'm talking to a friend who happens to speak Spanish, but umm, not really never..."

@27:33 “...I prefer that you speak to me in English”

As shown, there's a general preference for English to be spoken by SS, she states that she prefers when people speak to her in English and she prefers to address others in English. Statements like these provided insight into the discourse surrounding many second generation Cuban Americans who like SS, who prefer to speak in English. Some discourse surrounding Miami speakers mention that some have not full acquired English and thus there exist these calqued expressions and 'accents' as products of unsuccessfully acquiring English. But, as demonstrated, these occurring phenomena, are not due to unsuccessful obtainment of the English language, they are of course influenced by Spanish, but may be the product of a more complicated scenario of language interaction in Miami. As mentioned by SS a number of times, the Spanish and English interactions around Miami are complex and require speakers to have knowledge of both languages. SS's family dynamic alone is quite complicated, where SS is often switching languages between her own parents:

Tell me a little about your home, do you mostly speak Spanish? 
@20:40 “...umm with my parents, my mom, strictly Spanish, umm my dad English, like $99 \%$ of the time unless for some reason I have to explain it in Spanish cause my mom's involved in whatever we're talking about, umm my siblings, only English because I'm the most fluent in Spanish of the four. So they have a really hard time talking to my mom because they haven't picked up Spanish even after all these years....and my family [extended], they only speak Spanish..."

Although SS did not use some of the phenomena that were found in the task experiment, there we several other phenomena observed during the interview, further studies will need to be carried out in order to test the durability of these expressions as well:

@2:52 "...but most of the time I spent myself in chorus..."

Possibly derived from the Spanish expression:

la mayoría del tiempo me la pasé en chorus [the. Majority. Of the. time. Myself. it. Spent/passed. in chorus]

@13:13 “...l've never been the kind of person that mis-takes their trust... “

Mis-takes may be possibly derived from the Spanish expression: mal uso

[bad. use/handling.]

This expression is difficult to interpret, but what is noticed is that mistakes is definitely an alternative expression to a perhaps more standard expression like, disobey or misuse. Misuse resembles the Spanish expression, 
mal uso, thus the statement if put in a more standard construction may read, I've never been the kind of person that misuses/mishandles their trust.

@22:24 “...like she understands English, but in the same case she can't speak it back to you "

Possibly derived from the Spanish expression:

el mismo caso que

[the. same. case. as.]

'The same case as 'could be an alternative expression to the more standard expression, 'at the same time', as it is semantically similar to the Spanish form.

\subsection{Alexander Supertramp}

Alexander Supertramp or AS, was born in Miami to a Cuban American father, who was also born here and an Ecuadorian mother who was born in Ecuador. Thus, AS is difficult to classify in terms of which generation he belongs in, whether it's generation 2 or 3 , but whatever the case, AS is definitely a Miami born native and has spent his life here in Miami. AS, as with Maria and SS all express similar statements when they describe the complex Spanish and English language interactions that happen not only in their homes but also outside when responding to a variety of questions:

What languages do you speak? How did you learn them? 
@17:57 “...I speak Spanish and English. I learned Spanish from my parents and my grandparents. And I learned English from them as well and school and my peers..."

So how has it like, your mom speaks to English to you or does she tend to use Spanish?

@18:34 “...She tends to speak in Spanish, she learned English when she came here....so when I speak to her, she will rarely if ever speak to me in English.."

When you're talking back to her will you respond in Spanish?

@18:52 “Uh, no, I'll respond for the most part in English, sometimes I'll mix in between, like l'll say something in Spanish and then in midsentence l'll revert back to English..."

How about with your father, you say he grew up here, does he interact with your mother in English or Spanish?

@19:28 “Uh, I would say it's the same relationship that we have, I would say they speak more Spanish to each other, than English but I've heard him talk to my mother in English and she'll respond in Spanish."

Do you ever speak Spanish outside of your home? 
@20:34 "The only time I speak Spanish outside my home is at my job..."

How good is your Spanish?

@22:30 "On a scale of 1 to 10 , I would probably say between 3 and 4....'cuz I don't practice moderately so to certain degree I'm not as versed in it as I think I am..."

Statements like these again provide information on how Miami bilinguals use their languages in diverse situations as well as in their own homes. AS's interview demonstrates once again the preference for English among certain Miami bilinguals and the complexities of their bilingual interactions.

Although none of the task experiment phenomena were noted in AS's interview we did find one possible phenomena in the statement below when asked about all the details of producing a movie:

@6:27 “...Like dollies that help it move forward and back in like a really smooth process, so I've sort of had to tackle on finding all that to make the short..."

It's presumed that tackle on may be an alternative of a standard expression like, take on. However, the connection between Spanish and English here is difficult to find and this calque may not have any influence from 
Spanish and is just an innovative use of forms of to tackle something (to do it) and to take on.

\section{$6.4 \mathrm{I1}$}

I1 is a second generation Cuban American who was born and raised in Miami, she described how her mother was born in Cuba but came to the United States when she was only 7 years old. Further, upon arrival to the US, I1's mother, grew up in an almost entirely monolingual environment in Baton Rouge, Louisiana. Her father is a Venezuelan national, and her parents met at Louisiana State. She describes her parents living in Caracas, Venezuela for a period of time and then they came back to Miami after the birth of her older sister. Although there were no noted phenomena in I1's interview, she does describe the language situation as some of her peers have previously described it. This further provides evidence to the assumption that calqued expressions in Miami are not due to lack of proficiency in English but because of the complex language interactions among speakers.

What is language like in Miami?

@29:58 “...you can see things changing so rapidly because of the language contact... there's so many vibrant speakers and I think especially in Miami because Spanish is a high prestige language, and there isn't a penalty for speaking Spanish, people, even non-Spanish speakers, like Brazilian, Portuguese speakers I don't feel like people pay such a penalty for not speaking English." 
Even though many second and third generation participants seem to prefer English when conversing, I1 still notes the higher perceived status of Spanish than in other places where there's as much less intermingling of languages and such an acceptance towards each of them at the same time.

\subsection{Alex $\mathrm{MH}$}

Alex $\mathrm{MH}$ is a second generation Miamian, who was raised in Miami but whose parents, both her father and mother, were born in Peru. She described her grandparents and uncles and aunts on both sides, are all currently living in Peru. She also mentioned that she had many cousins living in Europe as well. Alex $\mathrm{MH}$, as the other participants describes her complex language interactions with her family and friends as most second generation Miamians have described:

So what language do they [parents] speak to each other?

@10:20 “...Spanish, purely Spanish for the most part. Unless my dad is telling my mom about something that happened at work then he'll say something like. English, English, English, but usually it's Spanish, they fight in Spanish, they talk in Spanish, they everything....for the most part at home everything in Spanish, my brother is really the only one that really tries to push the English, but I just think because I'm older, I realize the value of knowing two languages....cause he's been, losing it [Spanish] a bit, they're [parents] are trying to get him to use more Spanish, but it's not really working.." 
@11:19 'l'll speak to him [brother] in English, it's just easier, honestly it just depends on who's present, so if we're like sitting at the table having dinner....when they're [parents] there and we're having a conversation which is rare but when it does happen, l'll talk to him in Spanish then after a bit, l'll give up..."

@11:47 “...but sometimes he'll [brother] text me in Spanish and I'll respond in Spanish..."

Do you talk to your parents in Spanish?

@ 11:59 “...I talk to them in Spanish, I feel like they're more comfortable with that but sometimes it's a problem because sometimes if you're trying to explain something to them or make a point or like defined yourself, it's easier for me in English 'cause I talk English all day every day to everybody else but a little bit of pero no sé here and I don't even know what over there.....I don't access it [Spanish] as quickly as I used to...I'll get stuck more frequently than I used to..."

@13:20 “...for the most part I speak to them [parents] in casual Spanish..." 
Alex $\mathrm{MH}$ is not noted to have used any of the other phenomena that were included in the experiment tasks, however, she is noted to have used a popular expression and an additional expression:

Do you have any other family here?

@13:30 “... yes but you know how family's distance, and it's not for anything it's just that they live in..."

This expression is assumed to be derived from the Spanish expression:

No es por nada

Not. it is. for. nothing.

This expression translates literally from Spanish to English in this way. This alternative expression may be normally expressed as, it's not for any reason. A similar expression is mentioned in a popular Youtube video entitled Shit Miami Girls Say....and Guys Part 2:

@00:26 “...Not for nothing..”

This expression, like 'It's not for anything' mimics the structure of the Spanish expression above and could be interpreted as a calqued expression derived from Spanish and it is noted that this expression does stray away from a more standard form.

Additionally Alex $\mathrm{MH}$ states another expression that may be interpreted as a calque as well.

@33:33 “...everyday that I'm home speaking with my parents, I learn how to communicate myself better.." 
This structure demonstrates similar structure to Spanish as well as the reflective 'myself' is used when in English this verb would not require a reflexive pronoun as it may be used in Spanish. The expression in Spanish would read something like, cada día que estoy en casa con mis padres, aprendo como comunicarme mejor, which reads perfectly well in Spanish, but in English may vary from a standard definition as SAE does use a reflexive pronoun with the verb communicate.

\subsection{Discussion}

The participants in this study outline a very complicated and unique situation in Miami where English and Spanish are both utilized quite frequently by first and second generation speakers, however, there seems to be a preference in general for English, both in familial and social situations, thus there's no doubt that these speakers are proficient and L1 speakers of English. Although these first and second generation participants are able to navigate quite easily between Spanish and English depending on the context, they have all expressed a preference for speaking in English and noted that they can express themselves better in that language. So, to conclude, based on these participants, one can see that the intricacies of Spanish and English interaction in Miami provide an assumption that calqued expressions and lexico-semantic phenomena come from language contact situations and not from speakers less proficient in one language or the next. Further studies will need to be done in order to test the new lexico-semantic phenomena that have been discovered in these interviews. 


\subsection{Conclusions and Future Work}

The lexico-phenomena studied in this thesis present questions for further sociolinguistic, dialect and later enregisterment studies. This study has demonstrated that these lexico-semantic phenomena although have declined slightly in the task experiment, are still maintained and used by the first and second generation Latinos living in Miami, but also are used by those, mostly the second generation, who show a preference for speaking English. This finding is further supported by the phenomena that have been found in the sociolinguistic interviews used in this analysis. This demonstrates that the Miami English dialect consists of not only prosodic and phonological variants but also it is rich in lexical variations from calqued expressions and lexicosemantic phenomena originating from Spanish. This thesis study also provided insight into the complicated maneuvering of Spanish and English discourse among second generation Miami natives which may provide groundwork for further study on the origination of such calques and lexico-semantic phenomena.

A further investigation to complement these analyses may involve the study of enregisterment, which researches the progression of particular speech forms in the lexicon as they become recognized as indexical of speaker characteristics by a population of speakers. When the speech forms become generalized and accepted, the variant becomes enregistered. By connecting particular speech features with indexical meanings, linguists can begin to comprehend the ideological schemes that are attributed to certain social 
characteristics to the people who use these variants. The study of enregisterment is crucial to comprehending the social and linguistic environment's effect on how forms become possible accepted variants in a speech community.

In addition to a study of enregisterment on the lexicon of this emerging variety of English, further studies between other generations, like third generations of Cuban Americans will be needed in order to test the durability of calqued expressions in this generation as well.

Further, phenomena that extend to other Latinos who are not of Cuban descent, as shown in the preliminary result of the task experiment and the expressions of Alex $\mathrm{MH}$, who is of Peruvian descent, in her sociolinguistic interview, will need to be examined and aggregate more participants in order to test the durability of these phenomena in Non-Cuban Latinos and if those results will be similar or different to the Cuban generations. 


\subsection{References}

Alvord, Scott. 2010. Variation in Miami Cuban Spanish interrogative intonation. Hispania 93:235-255.

Atwood, E. B. 1953. A Survey of Verb Forms in the Eastern United States.

Carter, Phillip M. and Salvatore Callesano. 2014. Dialect perception in SpanishspeakingMiami: The interaction of top-down and bottom-up stimuli. Paper presented at New Ways of Analyzing Variation (NWAV) 43. Chicago, IL: October 26, 2014.

Carter, Phillip M., Lydda López, and Nandi Sims.. A First Look at Miami LatinoEnglish: Tracking Spanish Substrate Influence through Prosodic and VocalicVariation. Paper presented at New Ways of Analyzing Variation (NWAV) 43.Chicago, IL: October 26, 2014.

Carter, Lynch. 2015. Multilingual Miami: Current Trends in Sociolinguistic Research. Language and Linguistic Compass. Draft. Wiley.

Cerney, Jacob. 2009. An In-depth phonetic analysis of the Miami dialect. Unpublished Master's Thesis. Williams College.

Doernberger, Jeremy and Jacob Cerny. 2008. The low back merger in Miami. Universityof Pennsylvania Working Papers in Linguistics 14: 11-15.

Fought, C. 2003. Chicano English in context. Palgrave Macmillan.

Fuller, Janet.2013. Spanish Speakers in the USA. Spanish Language

Maintenance and Shift in the US. Multilingual Matters, Bristol, UK. pgs. 101,102

Fuller, J. M. 2013. Spanish Speakers in the USA (Vol. 9). Multilingual Matters.

Galindo, D. L. 1987. Linguistic influence and variation on the English of Chicano adolescents in Austin, Texas. University of Texas at Austin.

García, Ofelia and Ricardo Otheguy. 1988. The language situation of CubanAmericans. In Language Diversity: Problem or Resource?, eds. Sandra McKay and Sau-ling Wong, 166-192. Rowley, MA: Newbury House

Gilliéron, Jules, and Edmond Edmont. 1902. Atlas linguistique de la France. Vol. 36. Champion.

Gilliéron, Jules, and Edmond Edmont.1902."1910 Atlas linguistique de la France."Paris. GilliéronAtlas Linguistique de la France1903. 
Harvey, L.P.1967. Castilian Mancebo As A Calque Of Arabic 'ABD or how EL Mancebo de Arevalo got his name. Modern Philosophy. pgs. 130-132

Haugen, Einar.1950. "The analysis of linguistic borrowing." Language: 210-231. Huang, Yan. 2007. Pragmatics. Oxford University Press, New York. pgs. 135136.

Jenkins, Devin.2003. Bilingual Verb Constructions in Southwestern Spanish. Spanish in Context. Bilingual Review Vol 27 Issue 3 pgs. 195-204.

Johnson, E. 1996. Lexical Variation and Change in the Southeastern United States, 1930-1990.

Kiesling, Scott F. 2004. "Dude." American Speech 79.3: 281-305.

Kim, Ronald. American English Dialectology, A Historical Survery. 2009. A collection of papers of papers scheduled for presentation at the American Day conference. Tertium, Krakow.

Kurath, W. 1949. The News Bulletin of the Rocky Mountain Modern Language Association. Rocky Mountain Modern Language Association, Vol. 2, No. 2, p. 2.

Kurath, H., \& McDavid, R. I. 1961. The Pronunciation of English in the Atlantic States: Based upon the Collections of the Linguistic Atlas of the Eastern United States. University of Michigan Press.

Kurath, H., Hansen, L., Bloch, B., \& Bloch, J. 1939-1943. Linguistic Atlas of New England. Providence.

Labov, W. 1962. The social history of a sound change on the island of Martha's Vineyard, Massachusetts.

Labov, W. 1963. The social motivation of a sound change. WORD-JOURNAL OF THE INTERNATIONAL LINGUISTIC ASSOCIATION, 19(3), 273-309.

Labov, W. 1964. The social stratification of English in New York City (Doctoral dissertation, Columbia university.

Labov, W. 1972. Language in the inner city: Studies in the Black English vernacular. Vol. 3. University of Pennsylvania Press.

Labov, W. 1972. 13. The Social Stratification of (R) in New York City Department Stores. 
Labov, W. 1969. A Study of Non-Standard English.

Labov, W. 1994. Principles of linguistic change. Vol. 1: Internal features.

Labov, William. 2006. The social stratification of English in New York city. Cambridge University Press.

Labov, William, Sharon Ash, and Charles Boberg. 2006. Atlas of North American English: Phonetics, Phonology, and Sound Change. Berlin: Mouton/de Gruyter.

Larizgoitia, Javier Alberdi. 2010."A typology of calques. The calquing mechanism in cotemporary basque." Estudios de lingüística 24: 13-35.

Leap, N., \& Hunter, B. 1993. The midwife's tale: an oral history from handywoman to professional midwife. Scarlet Press.

Llopis, María Angeles Orts, and Ángela Almela Sánchez-Lafuente. 2009. "Translating the Spanish Economic discourse of the crisis: dealing with the inevitability of English loanwords." IJES, International Journal of English Studies 1: 133-157.

López Morales, Humberto. 2003. Los cubanos de Miami. Lengua y Sociedad. Miami: Ediciones Universal.

Lynch, Andrew. 2000. Spanish-speaking Miami in sociolinguistic perspective. Research on Spanish in the United States, ed. Ana Roca, 271-283. Somerville, MA: Cascadilla Press.

Lynch, Andrew. 2009a. A sociolinguistic analysis of final/s/ in Miami Cuban Spanish.Language Sciences 31:767-790.

Ma, R., \& Herasimchuk, E. 1971. The linguistic dimensions of a bilingual neighborhood. Bilingualism in the Barrio, 349-464.

Manea, Constantin, Manea, Maria-Camelia.2012. Further Remarks on the More Recent Anglo-American Loanwords in Romanian. Philologica Jassyensia. pgs. 290,292,297 (pg290)

McDowell,J.,and McRae,S. 1972. Differential response of the class and ethnic components of the Austin speech community to marked phonological variables. Anthropological Linguistics 14, 228-39. 
Mendoza-Denton, Norma. 2008. "Homegirls: Symbolic Practices in the Making of Latina Youth Styles." Malden, MA: Blackwell.

Millar, R. M., Barras, W., \& Bonnici, L. M. 2014. Lexical Variation and Attrition in the Scottish Fishing Communities. Edinburgh University Press.

Mullen, Kristen. 2014. A cross-generational analysis of Spanish-to-English calques in emerging Miami English. Paper presented at The Linguistic Association of the Southwest. San Diego. September.

Newman, Michael.2010."Focusing, implicational scaling, and the dialect status of New York Latino English1." Journal of Sociolinguistics 14.2: 207-239.

Otheguy, Ricardo, García, Ofelia, Roca, Ana. 2000. Speaking in Cuban. New Immigrants In the United States Readings for Second Language Educators. Cambridge University Press, Cambridge. pgs. 165-185

Orts Llopis, María Ángeles \& Sánchez-Lafuente, Ángela Almela.2009.

Translating the Spanish Economic Discourse of the Crisis: Dealing with the Inevitability of English Loanwords. International Journal of English Studies, pgs. $135-136$

Oxford Dictionaries.2015. Definition of Calque. Oxford University Press.

Pedraza, P. 1978. Ethnographic observations of language use in El Barrio. Unpublished ms.

Peirsman, Y., Geeraerts, D., \& Speelman, D. 2010. The automatic identification of lexical variation between language varieties. Natural Language Engineering, 16(04), 469-491.

Penfield, Joyce, and Jacob L. Ornstein-Galicia. 1985.Chicano English: An ethnic contact dialect. John Benjamins Publishing.

Poplack, S., Pousada, A., \& Sankoff, D. 1982. Competing influences on gender assignment: Variable process, stable outcome. Lingua, 57(1), 1-28.

Poplack, S. 1982. Sometimes I start a sentence in Spanish y termino en español: Toward a Typology of Code-Switching. In Spanish in the United States: Sociolinguistic Aspects, ed. J. Amastae and L. Elías-Olivares. Cambridge Univ. Press, New York. pgs 230-63.

Poplack, S., Pousada, A., \& Sankoff, D. 1982. Competing influences on gender assignment: Variable process, stable outcome. Lingua, 57(1), 1-28. 
Porcel, Jorge. 2006. The paradox of Spanish among Miami Cubans. Journal of Sociolinguistics 10: 93-110

Purnell, T., Salmons, J., Tepeli, D., \& Mercer, J. 2005. Structured Heterogeneity and Change in Laryngeal Phonetics Upper Midwestern Final Obstruents. Journal of English Linguistics, 33(4), 307-338.

Robinson, J. 2012. Lexical variation in the BBC Voices Recordings. English Today, 28(04), 23-37.

Roca, Ana. 1991. Language maintenance and language shift in the Cuban American community of Miami: The 1990s and beyond. In Language Planning, ed.David F. Marshall, 245-257. Amsterdam/Philadelphia: John Benjamins.

Santa Ana, O., \& Bayley, R. 2004. Chicano English: Phonology. A handbook of varieties of English, 1, 417-434.

Schreier, D., Trudgill, P., Schneider, E. W., \& Williams, J. P. (Eds.). (2010). The lesser-known varieties of English: an introduction. Cambridge University Press.

Silva-Corvalán, Carmen, and Andrés Enrique-Arias. 2001. Sociolingüística y pragmática del español. Georgetown University Press.

Silva-Corvalán, C. 2004. Spanish in the Southwest. Finegan and Rickford (eds.), 205-29.

Silva-Corvalán, Carmen. 2004. Spanish in the Southwest. Language in the USA, Themes for the Twenty-first Century. Cambridge University Press, New York. pgs. 205-229

Silva-Corvalán, Carmen. 2006. Bilingualism and Language Change: The Extension of ESTAR in Los Angeles Spanish. Language, Vol.62, No.3. Linguistic Society of America. pgs. 587-608

Thomason, Sara Grey.1999. On predicting calques and other contact effects.

Bilingualism: Language and Cognition,2, pg. 94

Trudgill, P. 1974. The social differentiation of English in Norwich (Vol. 13). CUP Archive.

Trudgill, P., \& Chambers, J. K. (1980). Dialectology.

Trudgill, P. (Ed.). 1984. Language in the British isles. CUP Archive. 
Trudgill, P. 1990. The dialects of England (p. 102). Oxford: Blackwell.

Trudgill, P. 1992. Introducing language and society. Penguin English.

Trudgill, P. 2002. Sociolinguistic variation and change. Oxford University Press.

Trudgill, P. 2003. A glossary of sociolinguistics. Oxford University Press.

Wenker, Georg. Sprachatlas, Deutscher.1927."Auf Grund des von Georg Wenker begründeten Sprachatlas des Deutschen Reichs in vereinfachter Form begonnen von Ferdinand Wrede, fortgesetzt von Walther Mitzka und Bernhard Martin. Marburg. Texte 1926-1956."

Wolfram, W. 1970. Sociolinguistic premises and the nature of nonstandard dialects. Communication Education, 19(3), 177-184.

Wolfram, Walt. 1970. Underlying representations in Black English phonology. Language Sciences 10 (April):7 12.

Wolfram, Walt. 1977. On the linguistic study of Appalachian Speech.Appalachian Journal 5:92 102.

Wolfram, Walt. 1981. A-Prefixing in Appalachian English. In William Labov (ed.), Locating Language in Time and Space. New York: Academic Press, 107 43.

Wolfram, W. 1981. Varieties of American English. Language in the USA, 44-68.

Wolfram, Walt. 1982. Language knowledge and other dialects. American Speech 57:3 18 .

Wolfram, Walt. 1987. On the divergence of Vernacular Black English. American Speech 62:40 48.

Wolfram, Walt. 1989. Structural variability in phonological development: Final nasals in vernacular Black English. In Ralph W. Fasold and Deborah Schiffrin (eds.), Language Change and Variation, Philadelphia/Amsterdam: John Benjamins, 301-32.

Wolfram, W., \& Fasold, R. W. 1997. Field methods in the study of social dialects. Sociolinguistics: A Reader and Coursebook. Palgrave, New York, 89115. 
Wolfram, Walt, Phillip Carter, and Beckie Moriello. 2004. Emerging Hispanic English: New dialect formation in the American South. Journal of Sociolinguistics 8: 339-358.

Wolfram, Walt. 2013. African American Speech in Southern Appalachia. In Nancy Hayward and Amy Clark (eds.), Talking Appalachian: Voice, Identity, and Community. Lexington: University of Kentucky Press. Pg. 81-93.

Zentella, Ana Celia. 1990. Lexical leveling in four New York City Spanish dialects:Linguistic and social factors. Hispania 73, 1094-1105

Zentella, Ana Celia. 2004. Spanish in the Northeast. Language in the USA, Themes for the Twenty-first Century. Cambridge University Press. pgs. 182-204 